Discussion Paper No. 05-46

\title{
Centralizing Tendencies in the Public Sector in Germany
}

Dan Stegarescu

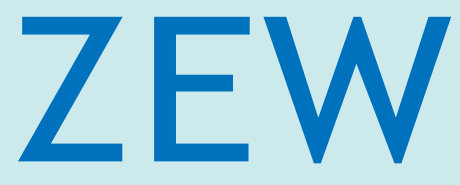

Zentrum für Europäische Wirtschaftsforschung $\mathrm{GmbH}$

Centre for European

Economic Research 
Discussion Paper No. 05-46

\title{
Centralizing Tendencies in the Public Sector in Germany
}

\author{
Dan Stegarescu
}

Download this ZEW Discussion Paper from our ftp server:

\section{ftp://ftp.zew.de/pub/zew-docs/dp/dp0546.pdf}

Die Discussion Papers dienen einer möglichst schnellen Verbreitung von neueren Forschungsarbeiten des ZEW. Die Beiträge liegen in alleiniger Verantwortung der Autoren und stellen nicht notwendigerweise die Meinung des ZEW dar.

Discussion Papers are intended to make results of ZEW research promptly available to other economists in order to encourage discussion and suggestions for revisions. The authors are solely responsible for the contents which do not necessarily represent the opinion of the ZEW. 


\section{Nontechnical Summary}

In general, the distribution of functions and decision-making powers across levels of government varies only slowly in the course of time. According to Popitz (1927), the long-term trend seems to suggest an almost ever-expanding role of the central government in the course of social and economic development. However, recent developments in industrial and developing countries since the 1970s indicate increasing devolution of government functions and revenues to lower levels of government.

This paper investigates the long-term trend and the underlying determinants of public sector centralization over time by taking a closer look at the experience of Germany from the creation of a unified state in 1871 to the present day. The following questions circumscribe the core of this examination. First, to what extent is it possible to detect a long-term trend of public sector growth and centralization in Germany's federal system? And, second, which are the factors determining this development, particularly after World War II?

Both the institutional and the quantitative review of the German history in fact document a significant growth of the public sector in line with Wagner's "law", together with a stepwise increase in the role of the central government, particularly due to the expansion of the welfare state. However, similarly to earlier studies, there is no clear support for a continuous and unavoidable process of centralization in the public sector, but rather for some distinct developments caused by the distortionary effects of two world wars and changes in the political system. Whereas the German Kaiserreich was a highly federalized state with the state level constituting the most important level prior to World War I, the Weimar Republic clearly emerged as a highly centralized federal state. The rise of the central government since 1871 seems to have come to an end in the aftermath of World War II, being replaced by a system of complex interconnections and cooperative decision-making between the central and the state levels. A significant difference consists in the fact that whereas prior to 1950 competencies have been transferred particularly from the state to the central level, after 1950 the upward shift occurred from local to central, and particularly to state governments. Therefore, Popitz' claims have to be assessed against the historical and political background specific to the interwar period.

The historical analysis, however, sheds some light on the role of institutional rules of decision-making, supporting the collusion hypothesis of Brennan and Buchanan (1980). Accordingly, only the specific institutional set-up after World War II, which provided for equal participation of the state level in decision-making concerning the distribution of revenues, as well as for the allocation of concurrent powers to the central government, enabled the creation of revenue cartels between the state and the central levels aimed at mitigating fiscal competition.

In order to explain the different development noticed after World War II and to test the validity of previous international studies for the specific German case, a time series regression analysis of the determinants of fiscal decentralization was run for the period 1950 to 2001. The results mostly support a recent panel analysis for OECD countries, indicating a significant decentralizing effect of per capita income growth during this time, whereas increasing population density and urbanization were associated with higher centralization. On the other hand, in contrast to other European countries, there is no clear evidence for a causal relationship between economic and European integration and fiscal decentralization in the case of Germany. This is probably due to weak preference heterogeneity and the implication of subnational governments in central policymaking.

In the end, these findings suggest that public sector growth and centralization are not in- 
evitable features of government following certain laws of nature. Therefore, this analysis allows no clear forecast with respect to the future allocation of functions and revenues across levels of government. In addition, as shown by the case of Germany, vertical government structures in federal countries barely change in the course of time, except owing to strong exogenous shocks. Apart from this, the long-term development is crucially influenced by country-specific institutions and preferences. Nonetheless, recent developments, such as the shift of government functions to the private sector, the reform of the welfare state, and reduced defense expenditures indicate a diminishing role of the state, and particularly of traditional central government activities, together with a loss of importance of national factors of location with advancing globalization and the transfer of powers to the European Union. 


\title{
Centralizing Tendencies in the Public Sector in Germany
}

\author{
DAn Stegarescu ${ }^{\dagger}$
}

\begin{abstract}
This paper investigates the long-term trend and the underlying determinants of public sector centralization in Germany from 1871 until today. The institutional and the quantitative review of the German history provides no conclusive evidence for a continuous process of government centralization as suggested by Popitz' "law", but rather for some distinct developments caused by the effects of wars and regime changes. Accordingly, whereas the role of the central government increased continuously at the expense of the state governments until World War II, after 1950 the state level regained importance. An empirical analysis for the period 1950 to 2001 reveals a significant decentralizing effect of per capita income growth, but provides no clear evidence for a causal relationship between economic and European integration and fiscal decentralization in the case of Germany.
\end{abstract}

Keywords: Public Sector Centralization, Popitz' Law, Determinants of Centralization, Germany

JEL Classification: F15, H72, H77

\footnotetext{
${ }^{\dagger}$ Centre for European Economic Research, L7,1, D-68161 Mannheim, Germany. Phone: +49 (0)621 1235 167. Fax: +49 (0)621 1235 223. E-mail: stegarescu@zew.de
} 


\section{Introduction}

With few notable exceptions, the distribution of functions and decision-making powers across levels of government varies only slowly in the course of time. This seems to be all the more true for federal countries. Therefore, the results of empirical analyses of government structures across countries which typically cover quite short time periods are mainly determined by the cross-sectional variation and might only be valid in the specific historical and economic context of the period of time considered there. The role of other forces shaping government structures over time remains often obscure. This suggests to take a long-term view on the development of the public sector in order to detect significant trends and to determine those factors actually underlying changes in the degree of fiscal decentralization over time.

An often expressed view postulates that the public sector evolves in conformity with some natural laws. De Tocqueville (1840), for example, predicts a natural tendency towards increasing centralization among democratic nations which results from the striving for equality and uniformity. Also, according to Wagner (1876) and Popitz (1927), the long-term trend seems to suggest an almost ever-expanding role of the public sector in general, and of the central government in particular, in the course of social and economic development. However, recent developments in industrial and developing countries since the 1970s indicate increasing devolution of government functions and revenues to lower levels of government. ${ }^{1}$

An inquiry into Germany's history is expected to shed some light on these issues, and particularly on the role of changing decision-making institutions. During the formation of Germany as a unified country in the 19th century, competencies have been transferred from the sovereign German states to the newly created central authority. Since then, Germany has passed through significant institutional, political and economic changes owing to two world wars and the recent reunification of West and East Germany. In particular, the alternating dominance of state and central level in national policymaking during its history are expected to have affected the formation of tax and expenditure cartels between subnational governments, as suggested by the collusion hypothesis of Brennan and Buchanan (1980). We can gain some general insight into the workings of decision-making institutions by looking at different historical periods.

For this purpose, this paper investigates the long-term development of the public sector in Germany from 1871 to the present day. The following questions circumscribe the core of this examination. First, to what extent is it possible to detect, as Wagner (1876) and Popitz (1927) suggested, a long-term trend of public sector growth and centralization in Germany's federal system? And, second, which are the factors determining this development, particularly after World War II?

Long-term trends in public expenditures and centralization have largely been investigated, both for Germany and for other industrial nations. ${ }^{2}$ These studies generally find no clear evidence in support of a continuous centralizing trend in the public sector following a law of nature. Rather, there are several, frequently disconnected, developments. As illustrated by Peacock and Wiseman (1961) for the United Kingdom, most significant phases of fiscal centralization are only attributed to the "displacement effect" of wars. Nonetheless, Blankart $(1999,2000)$ detects a "hidden" centralization process in Germany after World War II. The present analysis provides an updated overview of this development since 1871, particularly focusing on the institutional framework providing

\footnotetext{
${ }^{1}$ See Stegarescu (2004a) for a recent analysis of decentralization trends among OECD countries.

${ }^{2}$ See, e.g., Recktenwald (1962) and Hansmeyer (1967), and Behnisch et al. (2002) for Germany, and Hansmeyer and Zimmermann (1984), Recktenwald (1984), Kraus (1983), Pryor (1968), and Peltzman (1980), for Germany and other countries. Blankart (2001) also provides an investigation of Popitz' "law" for Prussia.
} 
for subnational participation in central decision-making.

With respect to the determinants of changing government structures, Peacock and Wiseman (1961), among other authors, postulate that government centralization increases with economic and technical progress. Focusing instead on the reverse causation between the vertical structure of the public sector and economic growth in Germany, Behnisch et al. (2002) detect a positive impact of the share of federal government expenditure in total public expenditure on productivity growth after World War II. On the other hand, Stegarescu (2004b) reveals a decentralizing effect of both per capita income and economic and European integration in a majority of OECD countries since 1970. The influence of economic development and of global and European integration on the degree of public sector decentralization is therefore investigated empirically in the present work for the specific German context after World War II. Generally speaking, the determinants of variations in the vertical government structure may considerably differ across countries and over time.

Similarly to earlier studies, the analysis of the long-term development in Germany reveals a stepwise increase in the role of the central government particularly until World War II, however, without providing clear support for a continuous and unavoidable process of centralization as suggested by Popitz (1927). Since 1950, then, the share of central government in total public expenditure and revenue decreased. The time series analysis of the effects of economic development and of economic and European integration on the degree of fiscal decentralization from 1950 to 2001 mostly supports previous panel analyses for OECD countries. Whereas per capita income growth exerted a decentralizing effect on public expenditure, there is no clear evidence for a causal relationship between economic and European integration and fiscal decentralization in the case of Germany.

The investigation proceeds according to the following plan. First, section 2 presents a historical description of Germany's vertical government structure since the foundation of the German Reich until today. Then, in the next section, the long-term development is quantified in terms of size and allocation of public expenditure and revenues. The regression analysis is carried out in section 4 , and conclusions are finally drawn in section 5.

\section{A Brief History of German Federalism}

This section aims at providing an inquiry into Germany's fiscal federal structure in historical terms from the creation of a unified state to the present day. ${ }^{3}$

\subsection{The German Kaiserreich (1871-1918)}

At the start, there had been no unified German state until the foundation of the German Kaiserreich in 1871. Although a single German economic area was already brought into being with the creation of the customs union (Zollverein) in 1834, the first attempt to unite all independent German states failed in 1848-49. The Norddeutsche Bund, a confederation of still sovereign states founded in 1867 and dominated by Prussia, represented the first political union, which was based on a customs union, common law, institutions and armed forces, and which was endowed with some own financial resources derived from individual state contributions.

\footnotetext{
${ }^{3}$ For the period before World War II, the description draws particularly on Burg (1992), Witt (1992), Neumark (1976), Gerloff (1913), Terhalle (1952), Schremmer (1994), and Döhler (2002), who also provide some historical figures.
} 
After the final unification of all German states in 1871, Germany's federal system until World War I was characterized by a strong asymmetry between a dominant Prussia, which had more than two thirds of total population and economic power, and provided both the German Kaiser and the Reichskanzler, and a multitude of smaller states and principalities. Though formally having equal powers, the democratically elected lower chamber of parliament, the Reichstag, remained rather weak as compared to the upper chamber, the Bundesrat, which consisted of representatives delegated by the state governments. The representative body of the sovereign states was the dominant legislative authority, being vested with certain prerogatives, such as an absolute veto power with respect to the federal budget and all federal legislation, and the right to dissolve the lower chamber and to take part in other important decisions of the central government, such as the declaration of war. Taking furthermore into account that small states had disproportionately strong representation in the Bundesrat, formally in the position to outvote Prussia, the German Kaiserreich can be described as a highly federalized state with the state level constituting the most important level prior to World War I.

In general, during the Kaiserreich government functions were clearly distributed between the central and the state level. The federal government was exclusively responsible for defense, foreign affairs, trade policy and certain economic services, particularly postal operations, and had to maintain the legal and economic unity. Within this context, federal laws were generally executed by state governments on their own behalf. The state as well as the local levels were predominantly responsible for almost all other expenditures. As a general rule, the state level was mainly concerned with higher authority functions, including administration, justice and police. Expenditure on culture and education were shared between the state and the local levels, the former being primarily responsible for universities, and science and research, the latter for schools. On the other hand, tasks related to welfare state and population, such as social assistance, health, housing, and environmental services were mainly performed at the local level.

Similarly to the USA and Switzerland, the Constitution of 1871 established a strict division of revenue sources and taxing powers, without providing any systematic mechanisms of policy coordination between the different fiscal tiers. Though not explicitly laid down in the constitution, indirect taxes and tariffs exclusively belonged to the central, direct taxes to the state and local levels. The states were completely autonomous to set up their own tax and financial system, and were exclusively responsible for tax administration. ${ }^{4}$ State taxes included first and foremost income, wealth, inheritance and profit taxes. Local governments generally shared in these revenues or were allowed to autonomously determine the rates for business and property taxes subject to certain limits and to raise additional charges to the state income taxes. Yet, the degree of local discretion varied significantly between the states. Finally, surpluses from state-owned enterprises constituted a further important revenue source, particularly for state and local levels.

Apart from this, according to Art. 70(2) of the Constitution, the Reich's current budget deficit had to be balanced by fiscal transfers of the states according to their population size, the Matrikularbeiträge. Though in principle the central level was allowed to introduce own taxes in parallel with the states, ${ }^{5}$ the expansion of central taxing powers was strongly opposed by the states. Therefore, the state contributions constituted initially the third most important financial resource of the central government. In contrast to this, exceptional expenditures, mostly for military purposes, were predominantly financed by public debts. In theory, the central level could indefinitely incur debts which, indeed, led to a strong rise of the Reich's public debt from zero in 1871 to approximately $9.1 \%$

\footnotetext{
${ }^{4}$ Note that no inter-state fiscal equalization existed at that time, neither by vertical, nor by horizontal intergovernmental transfers.

${ }^{5}$ This provision was, however, abolished in 1904.
} 
relative to GNP in $1914 .{ }^{6}$ At least with regard to its military expenditures, therefore, the central level was independent of the individual states.

Although the state level was able to defend its dominant position until the end of the Kaiserreich, nonetheless, the central level and, particularly, the Reichstag continuously gained ground at the expense of the states and the Bundesrat. This was particularly due to the introduction of social insurance in the 1880s, and to the fact that new tasks, such as the building of a modern navy and the acquisition of colonies were taken on by the central government. Particularly the central level's unlimited power to incur public debts was perhaps a major driving force of centralization during the German Kaiserreich. In the course of time, the central level was also increasingly involved in certain areas of traditional state competency, like science and academic research.

This process of growing importance of the central level was also reflected in increasing financial independence from state governments. With the introduction of the Reich's inheritance tax in 1906 - a central tax shared with the states - and even more so with the war contribution (Wehrbeitrag) created in 1913, the central level established its first own direct taxes. On the other hand, as revenues from tariffs increased in consequence of the protectionist trade policy, ${ }^{7}$ the states prevented the central government's independence by enacting the Frankensteinsche Klausel in 1879. According to this settlement, which was in force until 1904, the central level had to transfer all tariff and tobacco tax revenues exceeding 130 million Mark to the states, despite running a budget deficit. This led in the end to net payments to the states and rising debts of the central government. Due to the induced budget deficit, the individual states could continue to transfer its Matrikularbeiträge, therefore keeping the central level financially dependent on the states (Bismarck: "Kostgänger der Einzelstaaten"). However, the share of transfers received from the states in total tax and tariff revenues of the central government declined from $15-20 \%$ before 1880 to $3 \%$ in $1913 .^{8}$

\subsection{The Interwar Period (1919-1938)}

Besides abolishing the monarchy, the Weimar Constitution of 1919 crucially altered the German federal system. The central level, represented by a directly elected president who had extraordinary competencies, and the Reichstag as the lower chamber, now became the dominant level of government. The upper chamber of the German parliament representing the Länder governments, the Reichsrat, though formally having equal rights in terms of legislation, retained only a suspensive veto power which could be overruled by a qualified two thirds majority in the lower chamber.

The inevitable concentration of government functions at the central level, which usually occurs during long military conflicts, was consolidated after the war. The new Weimar Constitution transferred certain government functions from the state to the central level and also introduced new expenditures on social assistance and education which were previously assigned to the local level. Apart from this, war damage compensation formed a considerable part of the central budget.

The process of centralization during the Weimar Republic becomes even more evident with respect to the financial constitution. With the financial reform of Erzberger ${ }^{9}$ in 1919 the different tax laws of the states were replaced by a standardized tax system, the central government also receiving the exclusive right to raise and legislate most taxes

\footnotetext{
${ }^{6}$ See Neumark (1976: 99f.), and also Gerloff (1913).

${ }^{7}$ According to Schremmer (1994), the share of revenue from tariffs in total revenue of the central government rose from $25 \%$ in the 1870 s to $40-50 \%$ at the end of the 1890 s.

${ }^{8}$ See Neumark (1976).

${ }^{9}$ Note that this tax legislation was mainly in force until 1977.
} 
(Kompetenzkompetenz). Besides having exclusive competency for tariffs and consumption taxes, the central government had the ultimate decision-making power in terms of concurrent legislation over most direct and indirect taxes and framework legislation over state taxes and charges (Art. 8 of the Weimar Constitution), the Reichsrat having only a suspensive veto power. State governments were not allowed to levy surcharges on central taxes, and tax administration and collection was centralized. Consequently, the states lost their fiscal autonomy and became on their part financially dependent on the central level. Only few taxes, like business, property, building and other minor indirect taxes remained in the competency of state governments, though limited by central rules. ${ }^{10}$ To compensate them for the loss in financial autonomy, state and local levels shared in the yields of income, corporate and value-added taxes. Apart from this, fiscal equalization through vertical transfers was introduced for the first time, both at the state and the local levels.

With the beginning of the Nazi period in 1933, Germany ceased to be a federal system. The states were consolidated and entirely lost both their fiscal and political autonomy and the Reichsrat was dissolved. Consequently, and particularly with begin of remilitarization in 1935, most public expenditures and financial resources were allocated to the central level. Tax sharing was replaced by vertical central grants and the few remaining state taxes were finally allocated to the central or to the local level. By regaining in 1936 their right to determine the rates of the business and property taxes under certain limits imposed by the Reich, local governments retained a certain degree of fiscal autonomy. Terhalle (1952) suggests that the share of total tax revenues which was determined by central legislation increased from $50 \%$ in $1913-14$ to $98 \%$ in 1938.

\subsection{The Postwar Period (since 1949)}

After World War II, the government structure of the Federal Republic of Germany emerged as a compromise between two tendencies. On the one hand, a federalist current, represented by the Constitutional Convent and the Allies, supported strong autonomy of state governments and strict separation of expenditure and taxing powers. On the other hand, a unitarist current, represented by the Parliamentary Council, was in favor of a centralized federal state in the tradition of the Weimar Republic. ${ }^{11}$ Due to the pressures exerted by the Allies against the emergence of a strong central government, the newly created Länder finally obtained a stronger position as compared to the Weimar period.

In the tradition of the Weimar Constitution, Art. 72(1) and 105(2) of the new German Basic Law of 1949 provide for a wide range of concurrent legislation giving the central government the power to exhaust all aspects of a specific matter, the subnational entities retaining the power to legislate only as long as that matter has not been exhausted by the central government (Kompetenzkompetenz). Apart from this, the majority of general framework legislation is allocated at the central level, too. However, in contrast to the Weimar Republic, the upper chamber of the national parliament, the Bundesrat, which represents the state governments, ${ }^{12}$ is now involved with equal powers in decision-making concerning constitutional revision, the distribution of competencies and revenues, and national legislation carried out by state administrations. Particularly this last aspect led to an increase in the proportion of ordinary bills which had to be approved by the regional chamber from initially $10 \%$ to nearly two thirds nowadays. ${ }^{13}$

\footnotetext{
${ }^{10}$ In 1920 business and property taxes were transferred from the local to the state government.

${ }^{11}$ See, also, Döhler (2002) with respect to this controversy.

${ }^{12}$ Carrying on the tradition since 1871 , the present upper chamber of parliament is composed of representatives delegated by the Länder governments and subject to their instructions, each Land having a uniform vote.

${ }^{13}$ See http://www2.bundesrat.de
} 
Apart from concurrent and framework legislation, a new striking feature of today's federal system consists in increased policy coordination between the different levels of government. In line with this, joint public activities (Gemeinschaftsaufgaben), formally defined in Art. 91 of the Basic Law, are particularly carried out in areas related to transport and communication and other economic services. In addition, the primary responsibility of the state level in matters of culture and education is counterbalanced by considerable policy coordination after 1949, both between the different Länder and between the state and the federal level.

To comply with the demands of the Allies, a strict division of financial resources was initially implemented, however, mostly with respect to tax yields and tax administration, and less in terms of tax legislation. Despite allocating income and corporate tax yields exclusively to the Länder governments, Art. 106(3) of the Basic Law in its initial version of 1949 generally allowed the central government to participate in these revenues, provided approval of the Bundesrat. Following the financial reforms of 1955 and 1969, income and corporate taxes were ultimately transformed into shared taxes, along with the value-added tax. ${ }^{14}$ Shared taxes constitute since then on average $85 \%$ of total tax revenues of consolidated sub-central government. In addition to this, a complex system of fiscal equalization was set up in 1955 which, besides vertical grants, provided for the first time for financial transfers from rich to poor Länder, intended for the adequate equalization of divergent tax efforts.

On the other hand, concurrent legislative powers over most taxes, including state and local taxes, are assigned to the federal level in line with Art. 105(2). ${ }^{15}$ Only local governments regained in 1956 their pre-war autonomy, being allowed to determine the rates of the business and property taxes within certain limits set by federal legislation. Even though the yields of most important taxes were initially allocated to the state level, concurrent tax legislation on these taxes was de facto already assigned to the federal level from the beginning. Therefore, except for the transfer of certain minor taxes from the state to the central level, no significant increase in tax centralization can be noticed since then. There is, however, circumstantial evidence for a continuing tendency to cede or abolish certain state and local taxes, such as the wealth tax, the wage sum tax, or the tax on business capital, and, more recently, the motor tax, in exchange for increased participation in the common tax pool.

Consequently, although being able to exercise a crucial veto power on most legislative issues in the upper chamber of parliament, in return the state level today enjoys only a limited extent of complete autonomy, particularly with respect to tax-raising powers. This applies even more so for rather poor Länder which are dependent on central grants. Therefore, whereas the Kaiserreich and the Weimar Republic were characterized by the predominance of the state and, alternately, the central level, the Federal Republic of Germany is characterized by complex connections between governments at all levels, which is frequently referred to as Politikverflechtung. ${ }^{16}$ This framework has probably grown out of the desire for uniform living conditions after the war, and of the historically rooted fear of state fragmentation (Kleinstaaterei). Although there are policy areas in which one level's competency clearly supercedes other levels' competency, it can be said that no fiscal tier really enjoys complete autonomy in today's Germany.

Given this type of cooperative federalism, Hesse (1962) argued that the close interrelationship between governments at the federal, state, and local levels establishes a "unitary federation". However, it should be noted that this specific kind of horizontal and verti-

\footnotetext{
${ }^{14}$ Note that since 1969 and 1998, local governments also receive a fixed share in revenues from income and value-added taxes respectively.

${ }^{15}$ Note, also, that in line with Art. 123(1) the previous uniform tax system of the Weimar Republic remained in force, thus not allowing different tax laws of the states.

${ }^{16}$ See Scharpf et al. (1976).
} 
cal cooperation is not equivalent to centralization of policies resulting in a higher share of federal public goods and taxes. One should rather expect state governments to use their funds in their own interest, even if the general legal framework for their policies is laid down centrally and uniformly. The evidence indicates that despite very low tax autonomy, there is significant variation in expenditure patterns across the Länder. ${ }^{17}$

Despite significant centralization after World War I, the review of German history from the foundation of the German Reich in 1871 until today therefore provides no evidence for a continuous rise of central government's power, but rather for some distinct developments. Whereas the Weimar Republic clearly emerged as a highly centralized federal state, state governments regained importance after World War II, though only in terms of extended participation in cooperative decision-making at the central level.

The historical overview for Germany, however, supports the collusion hypothesis of Brennan and Buchanan (1980), according to which lower level governments may cooperate and form tax and expenditure cartels in order to mitigate fiscal competition and to reap higher rents. As already noticed by Blankart (2000), today's institutional framework facilitates the creation of revenue cartels between the state and the central levels. Both equal participation of the state level in decision-making concerning the distribution of revenues, and the allocation of concurrent powers to the central government seem to have made this possible. These mechanisms furthermore tend to impede any alteration of the status quo. It is not surprising then, that the recently failed efforts to reform Germany's federal structures excluded from the outset the transfer of autonomous taxing powers to the state governments. ${ }^{18}$ In contrast to this, despite participation in central decision-making, no cartelization was possible among state governments during the previous periods. Whereas the Weimar Republic was characterized by a predominant central government and weak state governments, during the Kaiserreich the central government lacked the power to ensure such revenue cartels among the highly autonomous state governments.

In the next section, these findings with respect to centralization of decision-making structures are verified by means of quantitative figures.

\section{Quantification of Long-Term Trends in the Public Sector}

In order to examine public sector growth and centralization in terms of the "laws" formulated by Wagner (1876) and Popitz (1927), this section quantifies the development of the public sector in Germany since the middle of the 19th century until today, both in general, as well as differentiated with regard to fiscal tiers.

\subsection{Growth of the Public Sector}

To begin with, according to Wagner (1876), state activity and particularly public expenditure are supposed to rise at a faster rate than output in the process of cultural and economic development, that is with increasing industrialization and agglomeration. ${ }^{19}$ This "historically inevitable" expansion of the public sector originates in the pressure of social and economic progress, and particularly, in the rising complexities involved, which

\footnotetext{
${ }^{17}$ See, e.g., Buettner et al. (2004).

${ }^{18}$ The only attempts are aimed at exchanging the yields of some minor taxes between the central and the state levels, without, however, providing for separate taxing powers.

${ }^{19}$ See Wagner (1876: 892-908). See, also, Peacock and Wiseman (1961), and Recktenwald (1962) for a critical assessment.
} 
require increased enforcement of law and order, and direct state participation in production and provision of economic and social services. Generally speaking, goods produced by the public sector are assumed to have a high income elasticity of demand, and so rising income per capita implies an increase in the public sector's share in economy.

However, this claim is rather based on statistical observation than on clear empirical evidence. $^{20}$ Based on an empirical study of public expenditures in Germany, Brecht (1932) provides some evidence that local expenditure per capita are supposed to increase disproportionately with population size and urbanization. However, the German literature has criticized this result because of lacking theoretical foundation and because the empirical evidence is doubtful. ${ }^{21}$

Taking into account that there are neither gross national product (GNP) figures for the nineteenth century, nor reliable public expenditure data for the period before World War I available, the public sector's role in Germany will be analyzed on the basis of the ratio of total public expenditures according to national income statistics as percentage of net national product (NNP). For the pre-1950 period, the analysis draws on the work of Hoffmann (1965) which, despite statistical deficiencies, comprises the most consistent and detailed compendium of historical data on Germany. ${ }^{22}$

However, note that any quantitative analysis of the public sector's role in the economy faces fundamental difficulties. First and foremost, the entire range of state activities tends to be understated by fiscal measures which represent only budgetary flows. Apart from this, for reasons of frequent changes in both the geographical as well as the statistical boundaries which delineate the public sector, it is quite complicated to measure exactly the scope of the public domain over a long period of time. One should bear in mind that especially in the 19th century statistics were incomplete and methodologically controversial and many economic terms, such as investments and national income, not clearly defined. Also because of significant changes in German territory and population, a comparison of the development after World War II with earlier periods is, even in relative figures, controversial.

Given this qualification, Figure 1 plots the ratio of total public expenditures as percentage of net national product at market prices (NNP). Concerning the period prior to 1913, the growth of the public sector (including social security) is characterized by a relatively steady, if not rapid, expansion. ${ }^{23}$ From a minimum at $7.1 \%$ in 1856 , the share of total public expenditures as a percentage of NNP more than doubled to $14.8 \%$ in 1913. According to Neumark (1976) this can particularly be explained by the increase of military and social spending, and increasing demands for public goods with economic development and population growth.

The period after World War I takes off with significantly higher public spending, which demonstrates the "displacement effect" of social and political upheavals, such as wars, noted by Peacock and Wiseman (1961). ${ }^{24}$ As any modern war economy transforms itself typically into a public sector-controlled state economy, the public sector's importance will automatically be much greater immediately after the war as in comparison to the pre-war level. According to the authors, large social and economic crises induce people to accept dramatic changes in tax burdens and institutions, and will impose new functions upon the government. This increase in the share of the public sector in economy is less

\footnotetext{
${ }^{20} \operatorname{Ram}$ (1987), e.g., provides some mixed results from a cross-country analysis. While there is some support for Wagner's hypothesis in time series, there is no clear evidence in cross-section estimates.

${ }^{21}$ See Kuhn (1993) for a survey of this literature.

${ }^{22}$ See the appendix for a description of data sources and definitions. Note that no reliable data are available for the periods around World War I and II.

${ }^{23}$ The two exceptional peaks in 1866 and 1871 are both due to temporarily extended military spending in relation to the Prussian-Austrian and Franco-German War, respectively.

${ }^{24}$ See Pryor (1968) for a critical discussion and an empirical test of the "displacement effect".
} 
Figure 1: Growth of the public sector in Germany, 1850-2003

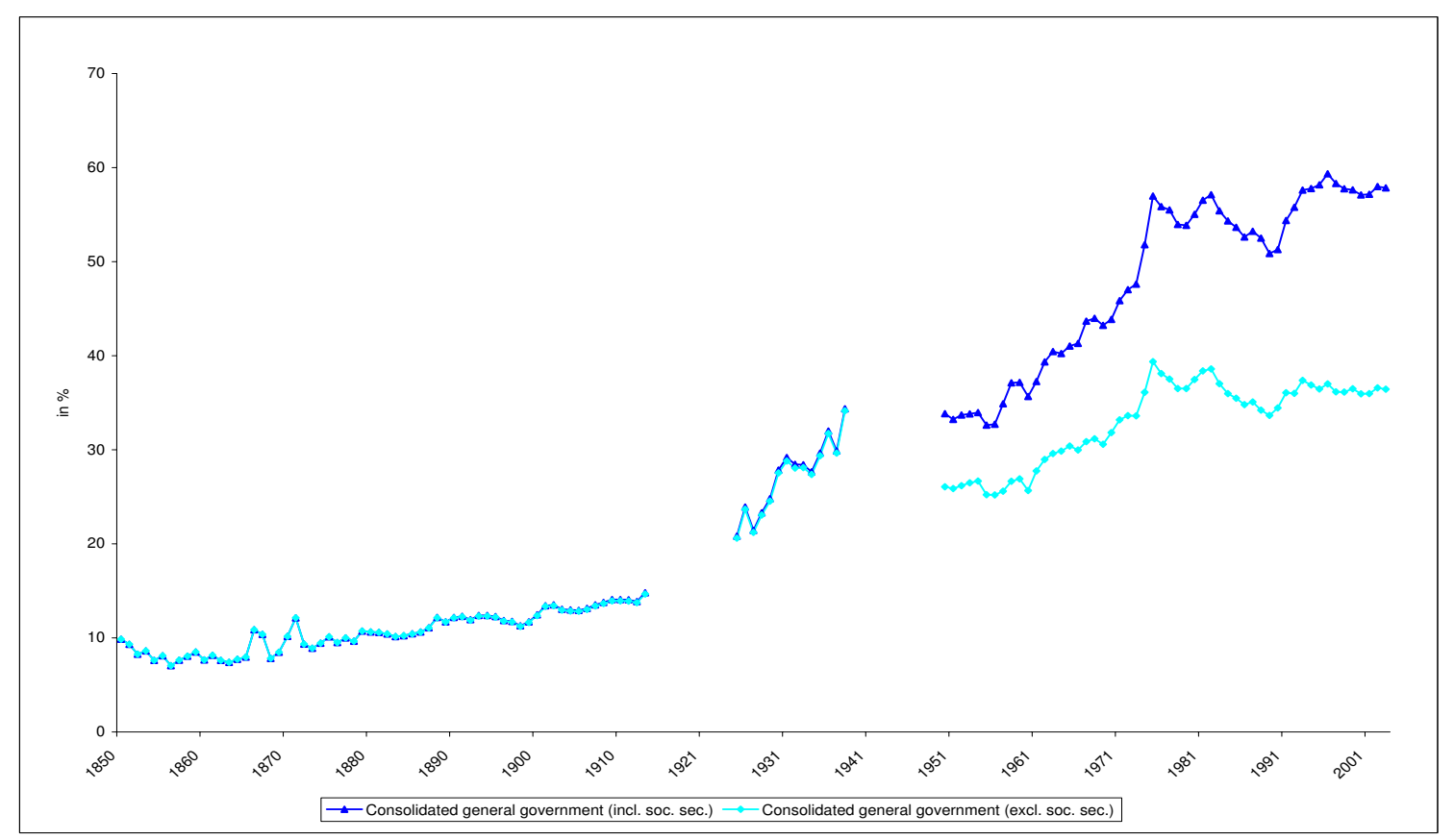

Note: Public expenditures of consolidated general government in $\%$ of net national product at market prices, according to national income accounts. Social security figures reported by Hoffmann (1965) are understated for the period 1850-1938. See the appendix for data sources and definitions.

likely to return to the old level before the crisis. However, besides the effect of the war, by far the biggest and most rapid growth of the public sector occurred from 1925 to 1938, the share of public expenditure in NNP increasing from $20.8 \%$ to $34.4 \%{ }^{25}$

This extraordinary expansion of the public sector is first of all due to a significant rise in public expenditures regarding education, housing, and social affairs (even without social insurance) owing to the extension of the welfare system during the Weimar Republic. ${ }^{26}$ Second, war damage compensation in accordance with the treaty of Versailles amounted to more than $10 \%$ of total public expenditures. ${ }^{27}$ Later on, Nazi Germany started its remilitarization and military expenditures increased considerably. Third, finally, whereas, in consequence of the Great Depression from 1929 to 1932, the national product actually declined, public expenditures remained mostly at their high levels, or even increased as, for example, in the case of welfare expenditures.

For World War II there is no such "displacement effect" observable. Starting with a level of $33.8 \%$ in 1950 , the ratio of public expenditures to NNP grew significantly during the sixties and seventies, and particularly during the period 1973 to 1975 . After reaching a peak of $57.1 \%$ in 1982 , there is a small decline in the public sector's share to $51.3 \%$ in 1990. However, after German reunification, additional public spending concerning the reconstruction of East Germany led again to an increase of the public sector size to another peak of 59.3\% in 1996 and a modest decline thereafter. As for the interwar period, the rapid growth of the public sector after World War II is mainly due to the extension of the welfare state. Excluding social security, the size of the public sector only increases from $26.1 \%$ in 1950 , which is slightly lower than the pre-Nazi era level (1933: $28.1 \%$ ) to $36.5 \%$ in 2003.

\footnotetext{
${ }^{25}$ Including all social insurance expenditure, Andic and Veverka (1963) even report an increase of the public sector's share from $23.4 \%$ to $37.9 \%$ during this time. However, these figures are not strictly comparable.

${ }^{26}$ See, in general, Recktenwald (1962, 1975), and Neumark (1976).

${ }^{27}$ See Statistisches Bundesamt (1972).
} 
In conclusion, the general trend from the middle of the nineteenth century to the present day indicates an increase of the public sector share in the economy by more than six times over the past 150 years: from an average of 9 percent for 1850-1855 to nearly 58 percent in 1998-2003. An empirical verification strongly supports this positive trend for the entire period of observation, as well as for the individual periods (see columns 1 and 2 in Table 1 below). However, if extra expenditures due to German reunification are regarded as short-time exceptional, the development since 1982 seems to point to a considerable slowdown in public sector growth.

\subsection{The Process of Public Sector Centralization}

\subsubsection{Positive Theories of Government Centralization}

Certain authors postulated that there is an inevitable tendency towards centralization of the public sector in the course of social and economic development. With respect to Germany, Popitz (1927) observed that the central government got increasingly involved in the affairs of state and local governments during the transition from the Kaiserreich to the Weimar Republic. ${ }^{28}$ Assuming that apart from a few original tasks of central and local governments, there are no clear criteria for the distribution of most functions among different levels of government, he predicts that particularly competencies of state governments tend to be attracted by the central government over time. Apart from this, as a consequence, the delimitations of areas of central and state government activity are expected to become increasingly blurred.

Different reasons are given in support of the increasing dominance of the central government. First, Popitz argues that an integrated economic area and the uniform supply of welfare services and living conditions require central legislation. ${ }^{29}$ The resulting costs for the state governments may subsequently be taken over by the central government, too. Second, lacking financial resources and considerable inter-jurisdictional differences in size and tax efforts impede state and local governments to execute central government legislation and to overcome emergency situations. Since the central level naturally benefits from a larger elasticity of revenues, it can provide financial assistance to the state governments, and also possesses more opportunities to extend its scope of public expenditures. For example, it can be observed that new and innovative public policy areas, such as transport in the 1920s, tended to be allocated first and foremost at the central level. And finally, it is because of the political preponderance of the lower chamber of parliament, the Reichstag, that popular demands, particularly related to the welfare state, tend to be increasingly addressed to the central state.

Generally speaking, the automatic "force of attraction of the central state" (Popitz, 1927: 349) is expected to entail an upward shift of both functions and financial resources from the state to the central level of government. However, Popitz mixes normative and positive perspectives on the development of the public sector, and his conclusions are highly controversial. ${ }^{30}$ For example, he postulates that efficiency and economical budget appropriation is only achieved through centralized administration. Whereas the political dominance of the democratically elected lower chamber of parliament and increasing demands for uniform living conditions certainly acted in favor of a stronger central government, it is not necessarily clear that an integrated economic area requires policy

\footnotetext{
${ }^{28}$ A similar centralizing tendency in the public sector is also predicted by Bryce's law for the USA, see Blankart (2001).

29 "Die Entwicklung des Deutschen Reiches [...] zeigt, [...] dass eine einheitliche Wirtschaft auf dem Gebiete des Rechts und der Gewerbeförderung zum mindesten gemeinsame Gesetzgebung voraussetzt [...]", Popitz (1927: 347).

${ }^{30}$ See Albers (1964), Recktenwald (1984), Hansmeyer and Zimmermann (1984), Hansmeyer (1967), Kraus (1983) and Blankart (2001) for a critical discussion of Popitz' law. According to Meyer (1998), Popitz' approach provides no adequate explanation of the process of centralization at the European level either.
} 
centralization and that smaller state governments naturally lack financial resources to fulfil their tasks. Also, inter-state disparities may be addressed by fiscal equalization payments without the intervention of the central state.

The predictions of Popitz' "law" have to be assessed against the specific historical and political background of the Weimar Republic, particularly the consequences of the war and the collapse of the monarchy which generated a centralist democratic current and led to the deprivation of powers of the state governments after the financial reform of Erzberger in 1919. Therefore, it rests an open issue whether Popitz' conclusions represent a law of nature and can be simply extrapolated to other periods of time.

Peacock and Wiseman (1961) also suggest that the process of economic growth generates pressures for the movement of responsibility for public functions to higher levels of government, however, without stating whether this applies at the central or at intermediate levels. ${ }^{31}$ They mention particularly technical progress and improvements in transport and communication, which are assumed to generate pressures for improved and more uniform standards of public services and to increase the efficient size of economic and administrative units. Increasing externalities of public goods, especially associated with the advancing of urbanization in the course of economic development, tend to further support centralization. However, strictly speaking, spillovers could be dealt with alternatively by policy coordination or fiscal transfers between the jurisdictions involved.

The "displacement effect" of wars is also mentioned by Peacock and Wiseman (1961) as another reason for increasing centralization. They suggest that public sector growth and centralization may occur concomitantly as the result of the same social crises. Accordingly, people are supposed to accept more easily centralization of government functions and revenues and abrogations of local autonomy during periods of war, increased social cohesion further supporting demands for uniform standards and policies. After the war, along with war-related commitments, such as public debt and war damage compensation which are generally incurred by the central level, higher central government expenditure do not return to the pre-war levels.

\subsubsection{Allocation of Expenditure and Revenue by Fiscal Tiers}

In the following, these hypotheses are verified for Germany by means of descriptive statistics. A quantitative examination of long-term trends in the vertical structure of public expenditure and revenue faces serious difficulties, in particular regarding the period until 1913. ${ }^{32}$ We focus, first, on the allocation of public expenditure by fiscal tiers, excluding social security.

According to Figure 2, starting from 29.3\% in 1881, the central government's share of total public expenditures seems to have remained rather stable until 1913. At the same time, there is a concomitant increase of spending at the local level. In line with Brecht's "law", Tilly (1997) notes that municipal government expenditures, especially driven by investment activity, grew clearly faster than the national product during this period. Particularly the process of urbanization is assumed to have forced municipalities

\footnotetext{
${ }^{31}$ Note, however, that the authors also mention the possibility of opposite effects, consisting in concomitant pressures to preserve local autonomy.

${ }^{32}$ Although the Reichsschatzamt (1908) provides data for some single years, it is important to note that these figures are only of limited use and reliability, since the local level is not adequately taken into account. Hoffmann (1965) also provides some long times series, yet, only for the allocation of administrative public spending across levels of government since 1850 . We use the estimates of Andic and Veverka (1963) for the period until 1913 which rely on expenditures made directly by the different levels of government (Unmittelbare Ausgaben) and reported by financial statistics (Finanzstatistik), which exclude transfers to other levels of government. Only five observations are available for this early period. After 1925, data reported by Kraus (1983) and the Statistisches Bundesamt are employed, which, however, draw on self-financed expenditure (Nettoausgaben), that is total expenditure excluding transfers received from other levels of government. See the appendix for more details on data sources and definitions.
} 
to expand their traditional activities and to take on new functions, such as the provision of local infrastructure. ${ }^{33}$ This development seems to have taken place at the expense of the state level, as there is a strong decline of the state level's share of total public expenditures from $44.4 \%$ in 1881 to $35.5 \%$ in 1913 . Consequently, in quantitative terms, with a share of $36.7 \%$ in 1913 local government emerged as the most important fiscal tier in the run-up to World War I, replacing the state level which, however, continued to play an important role.

Figure 2: Allocation of total public expenditures (excluding social security) by fiscal tiers, Germany, $1881-2001$

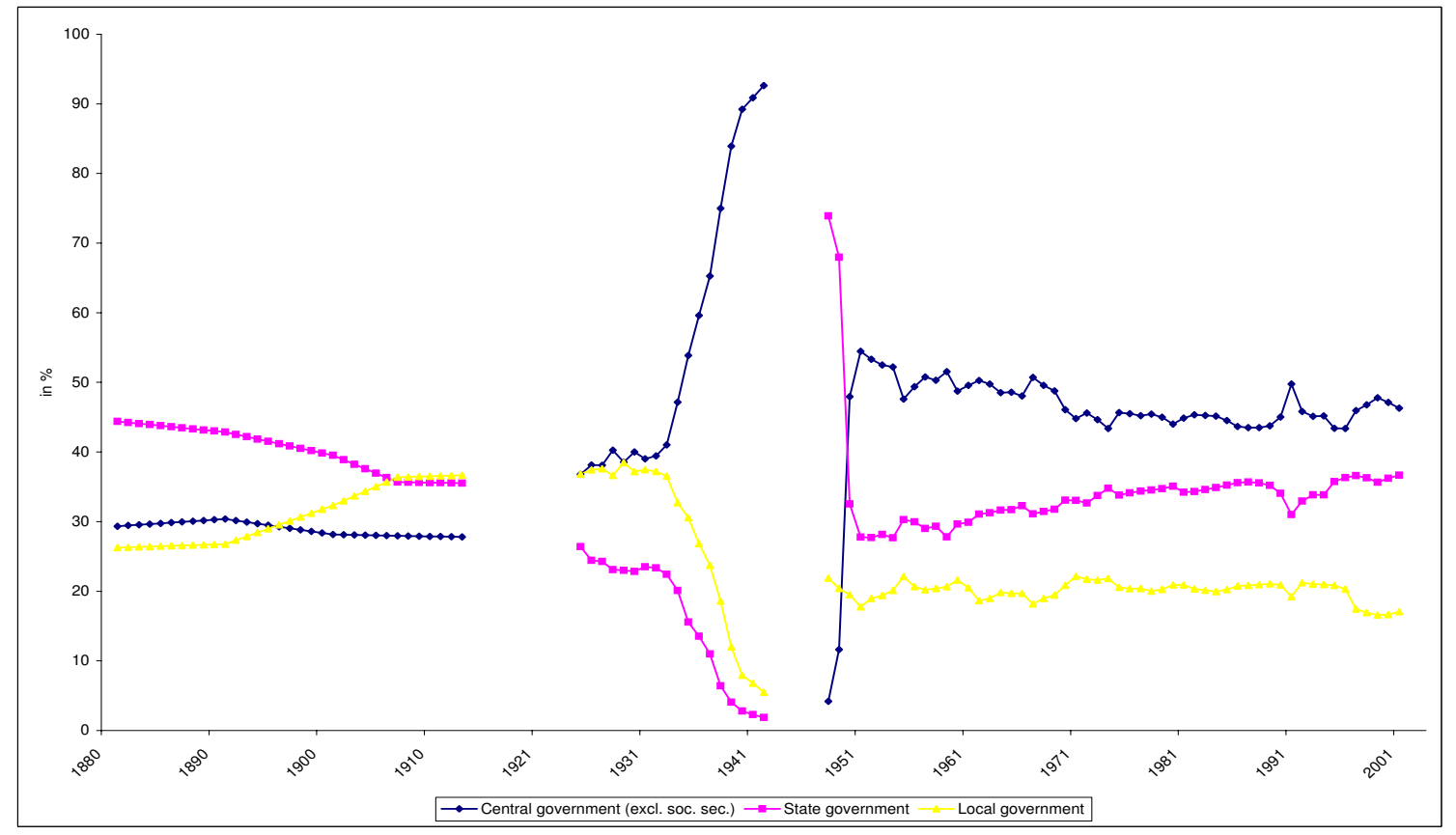

Note: Public expenditure by level of government in \% of total expenditure of consolidated government, excluding social security and payments to the EU. Due to different expenditure definitions, the time series 1881-1913 and 1925-2001 are not strictly comparable. See Table 3 in the appendix for detailed figures.

As regards the period after World War I, the evidence clearly supports the "displacement effect" of wars with respect to the vertical government structure. During the Weimar Republic from 1925 to 1932, the quantitative picture reflects the constitutional reassignment of powers noted above, showing that particularly the central level increased in importance, whereas the state level's role continued to decline. Accordingly, the central level starts with a much higher share of total public expenditures of $36.8 \%$ in 1925 , particularly due to spending on social assistance and war damage compensation, and further expanded, while the state government's share declines at $26.4 \%$ in 1925 and even $23.4 \%$ in 1932 , being clearly surpassed by the local government which mostly rests at its pre-war level of approximately 37\%. ${ }^{34}$ This development is in line with Popitz' observation that state government competencies are increasingly taken over by the central government.

During the Nazi era, the central government's share of total public expenditures made up as much as 75\% in 1938 before the outbreak of World War II. With gradual transformation into a war economy, the local and, above all, the state level become insignificant,

\footnotetext{
${ }^{33}$ For example, Legler et al. (1988) find a similar increase of local spending towards the end of the 19th century in the U.S., arguing that this gain in local spending reflects the process of urbanization.

${ }^{34}$ Note that due to different expenditure definitions, the time series before and after World War I are not strictly comparable. Generally, the degree of decentralization is slightly lower in case of self-financed expenditure reported after 1925.
} 
with a share of $18.6 \%$, and, respectively, $6.4 \%$.

The figures also reflect the significant system change which occurred after World War II. The most important consequence of the war was the re-emergence of the state level, which in effect changed its position with the local level. The Federal Republic of Germany starts in 1950 with a substantially higher share of central government expenditures as compared to the pre-Nazi period. However, particularly due to decreasing defense and war compensation spending, the central level's share of total public expenditures significantly declined from $54.5 \%$ in 1951 to $46.3 \%$ until $2001 .{ }^{35}$ The state level's share increased instead during the same period of time from $27.8 \%$ to $36.7 \%$, which comes closer to its level at the end of the Kaiserreich. On the other hand, starting at its preWorld War II level, the local level's share increased only slightly from $17.8 \%$ in 1950 to $20.9 \%$ in 1990 , only to decline again after German reunification to $17.1 \%$ in 2001 . Therefore, despite the higher initial level of centralization, the decrease in the share of central government expenditure thereafter and the simultaneous gain in importance of the state level clearly contradict Popitz' predictions for the period after World War II.

This long-term development on the expenditure side is mostly confirmed when taking a look at the revenue side. Due to the lack of sufficiently disaggregated time series data, the figures drawn from public finance statistics could not be adjusted for taxrasing powers of state and local governments. As depicted by Figure 3, the share of tax revenue accrued to the central level increased considerably, particularly during the interwar period, from $40.3 \%$ in 1913 to $49 \%$ in 1932 and to $67.3 \%$ in 1937 . However, it decreased again after the war from a peak of $62.3 \%$ in 1955 to its former level at the end of the Weimar Republic until 2001. At the same time, the state level's share of tax revenue decreased continuously from $35.1 \%$ in 1881 to only $10.7 \%$ in 1937 , whereas after the war the development went in the opposite direction, from $26.3 \%$ in 1955 to $38.7 \%$ in 2001, which is even higher as compared to the level during the Kaiserreich.

This development, again, took place at the expense of the local government. The share of total tax revenues accrued to local governments first increased from $25.9 \%$ in 1881 to $37.2 \%$ in 1913, surpassing the state government's share since the 1890s. This development is particularly due to the expansion of tax revenues of Prussian local communities, which accounted for the largest part of local government expenditure and revenue in Germany and enjoyed considerable tax autonomy. Apart from the local business and property taxes, particularly their right to levy a local surcharge on the state income tax significantly contributed to this development. ${ }^{36}$ After the war, however, the local government's share of tax revenues continuously decreased from a share of $30.3 \%$ in 1925 to $11.9 \%$ in 1950 , and remained relatively constant until the present day.

Note, however, that particularly the state level's tax revenue share misrepresents the extremely low degree of tax-raising autonomy of the states after World War II. Unadjusted tax revenue figures therefore overestimate the role of the state level more seriously than expenditure figures. According to the calculations of Stegarescu (2004a) which take taxraising powers of sub-central government into account, during 1973 to 2001 a relatively constant average share of $93 \%$ of total tax revenue of consolidated general government resulted from federal or concurrent legislation. These figures therefore support again the collusion hypothesis of Brennan and Buchanan (1980) for Germany, indicating that the increasing share of the state level in total public expenditure and revenue after World War II was conversely associated with a low degree of tax autonomy.

A continuous rise of the share of central government expenditure becomes, however,

\footnotetext{
${ }^{35}$ The great leap in Figure 2 after 1948 results from the fact that a central government was not installed until creation of the Federal Republic in 1949.

${ }^{36}$ See also Neumark (1976) and Blankart (2001) with respect to this.
} 
Figure 3: Allocation of total tax revenue (excluding social security) by fiscal tiers, Germany, 1881-2001

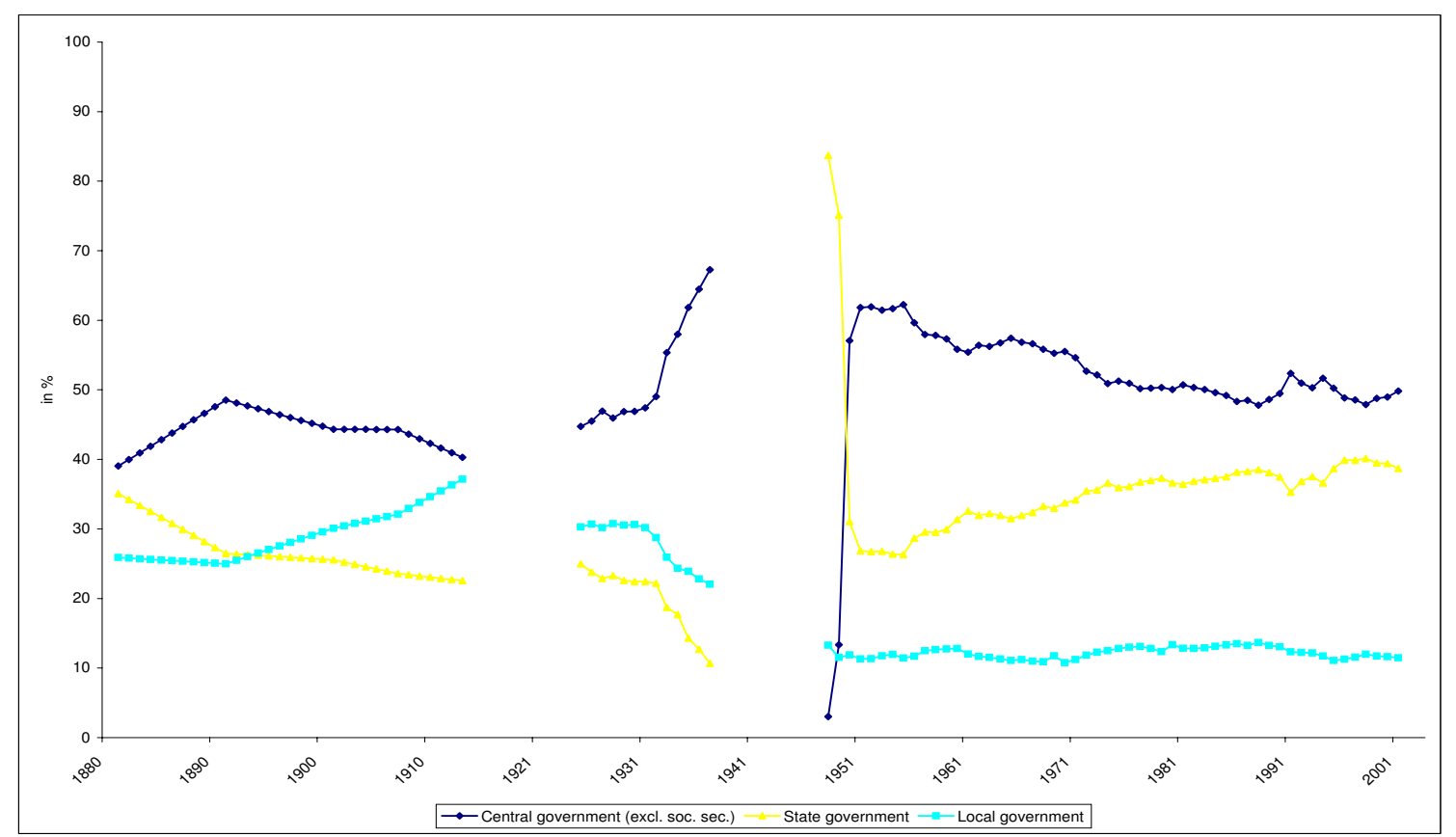

Note: Tax revenue by level of government in $\%$ of consolidated tax revenue, excluding social security and payments from the EU. See Table 4 in the appendix for detailed figures.

evident when taking social security as a part of the central level into account. ${ }^{37}$ Beginning with the introduction of the social insurance in 1885, the share of central government in total public expenditure including social security nearly doubled, increasing from $34 \%$ in 1891 to $67.2 \%$ in 2001 . Whereas in the pre-1914 and post-1950 periods there is a moderate increase, the figures for the interwar period reflect the drastic expansion of the welfare state during the Weimar Republic, particularly induced by the economic crisis.

Indeed, a quantitative verification indicates significant centralization trends in public expenditure for all periods only in case of including social security (see Table 1, column 3 ). When excluding social security (columns 4 and 6), a centralization trend is only statistically confirmed for the interwar period, whereas during the period before World War I and from 1950 to 1990, the central government's share of public expenditure or tax revenue tended to decrease. The decentralization trend since 1950 is also confirmed when focusing on government functions which might be provided at sub-central levels according to the theory of fiscal federalism, thus additionally excluding defense spending (column 5).

\subsubsection{Allocation of Government Functions by Fiscal Tiers}

In general, changes in the degree of fiscal decentralization over time are either due to shifts in the assignment of functions and revenues between fiscal tiers, including also the introduction of new tasks, or to divergent rates of growth of expenditure and revenue across levels of government related to different demand patterns. Therefore, next, we take a closer look at changing patterns in the allocation of government functions by level of government in order to assess Popitz' predictions concerning the appropriation of state functions by the central government.

\footnotetext{
${ }^{37}$ See Figure 5 in the appendix.
} 
Table 1: Trends in public sector growth and decentralization, Germany, 1850-2003

\begin{tabular}{lcccccc}
\hline \hline Period & \multicolumn{2}{c}{ Dep. variable: } & & & \\
& Publ. & Publ. & Decen. & Decen. \\
& exp. & exp. & exp. & Decen. & exp. \\
exp. & $\begin{array}{c}\text { Decen. } \\
\text { taxes } \\
(1)\end{array}$ & $(2)$ & $(3)$ & $(4)$ & $(5)$ & $(6)$ \\
\hline $1850-2003$ & $.005^{\star \star \star}$ & $.003^{\star \star \star}$ & $-.004^{\star \star \star}$ & $-.002^{\star \star \star}$ & $-.005^{\star \star \star}$ & $-.001^{\star \star \star}$ \\
& $(.000)$ & $(.000)$ & $(.000)$ & $(.000)$ & $(.000)$ & $(.000)$ \\
No. obs. & 132 & 132 & 84 & 99 & 99 & 98 \\
$\mathrm{R}^{2}$ & .911 & .908 & .775 & .447 & .705 & .176 \\
Adj. $\mathrm{R}^{2}$ & .910 & .908 & .772 & .442 & .702 & .168 \\
\hline $1850-1913$ & $.001^{\star \star \star}$ & $.001^{\star \star \star}$ & $-.002^{\star \star \star}$ & $.001^{\star \star \star}$ & $-.001^{\star \star \star}$ & .000 \\
& $(.000)$ & $(.000)$ & $(.000)$ & $(.000)$ & $(.000)$ & $(.000)$ \\
No. obs. & 64 & 64 & 33 & 33 & 33 & 33 \\
$\mathrm{R}^{2}$ & .848 & .844 & .785 & .765 & .805 & .010 \\
\hline $1925-1938$ & $.009^{\star \star \star}$ & $.009^{\star \star \star}$ & $-.023^{\star \star \star}$ & $-.027^{\star \star \star}$ & $-.014^{\star \star \star}$ & $-.019^{\star \star \star}$ \\
& $(.001)$ & $(.001)$ & $(.003)$ & $(.005)$ & $(.004)$ & $(.002)$ \\
No. obs. & 14 & 14 & 14 & 14 & 14 & 13 \\
$\mathrm{R}^{2}$ & .860 & .864 & .823 & .685 & .555 & .848 \\
\hline $1950-1990$ & $.007^{\star \star \star}$ & $.003^{\star \star \star}$ & $-.000^{\star \star}$ & $.002^{\star \star \star}$ & $.001^{\star \star \star}$ & $.003^{\star \star \star}$ \\
& $(.000)$ & $(.000)$ & $(.000)$ & $(.000)$ & $(.000)$ & $(.000)$ \\
No. obs. & 41 & 41 & 26 & 41 & 41 & 41 \\
$\mathrm{R}^{2}$ & .857 & .767 & .169 & .757 & .420 & .906 \\
\hline $1991-2003$ & .001 & -.000 & $-.003^{\star}$ & -.000 & -.001 & $.003^{\star \star \star}$ \\
& $(.001)$ & $(.000)$ & $(.001)$ & $(.002)$ & $(.002)$ & $(.001)$ \\
No. obs. & 13 & 13 & 11 & 11 & 11 & 11 \\
$\mathrm{R}^{2}$ & .197 & .038 & .314 & .001 & .037 & .547 \\
\hline \hline
\end{tabular}

Note: Coefficients and standard errors (in brackets) of OLS regressions on a linear trend for different periods of time. ***, $* *$, and $*$ indicate significance at $1 \%, 5 \%$ and $10 \%$ levels, respectively. Total public expenditure according to national income statistics, either including (1) or excluding social security (2), as percent of net national product at market prices. Degree of expenditure decentralization: sub-central government expenditure according to financial statistics, as percent of consolidated public expenditure, either including social security (3), excluding social security (4), or excluding social security and defense (5). Degree of tax decentralization: sub-central government tax revenue - irrespective of decisionmaking autonomy - according to financial statistics, as percent of total tax revenue (6). Certain figures are interpolated for the periods 1881-1913 and 1959-1974. See the appendix for data sources and definitions.

A general problem consists in changing classifications of expenditure according to government functions in the course of time. Based on public finance statistics and the classifications used by Andic and Veverka (1963) and Statistisches Bundesamt, Figures 6 to 8 in the appendix illustrate significant changes in the functional composition of the expenditure of the different levels of government from 1913 until today. In general, the common trend in the central government budget indicates a decrease in the proportion of expenditure related to administration, defense, and law \& order, and a concomitant rise of activities related to social assistance, economic services, and education. These changes are also reflected by the degree of centralization of selected government functions, as presented below in Figure 4.

In terms of the vertical assignment of government functions, the figures indicate a clear centralization trend particularly with respect to economic services which include transport, communication and economic development, among others, and to a lesser extent, with respect to law \& order, education and health after 1950. Accordingly, the central government's share of total transport and communication expenditures rose from $6.2 \%$ in 1913 to a peak of $50.8 \%$ in 1976, subsequently decreasing to $42.6 \%$ in $2001 .{ }^{38}$ A similar development pattern can be observed for other expenditure on economic services, too.

\footnotetext{
${ }^{38}$ Table 5 in the appendix provides some period-averaged figures on the allocation of public expenditure by government functions.
} 
Figure 4: Degree of centralization by government function, Germany, 1913-2001

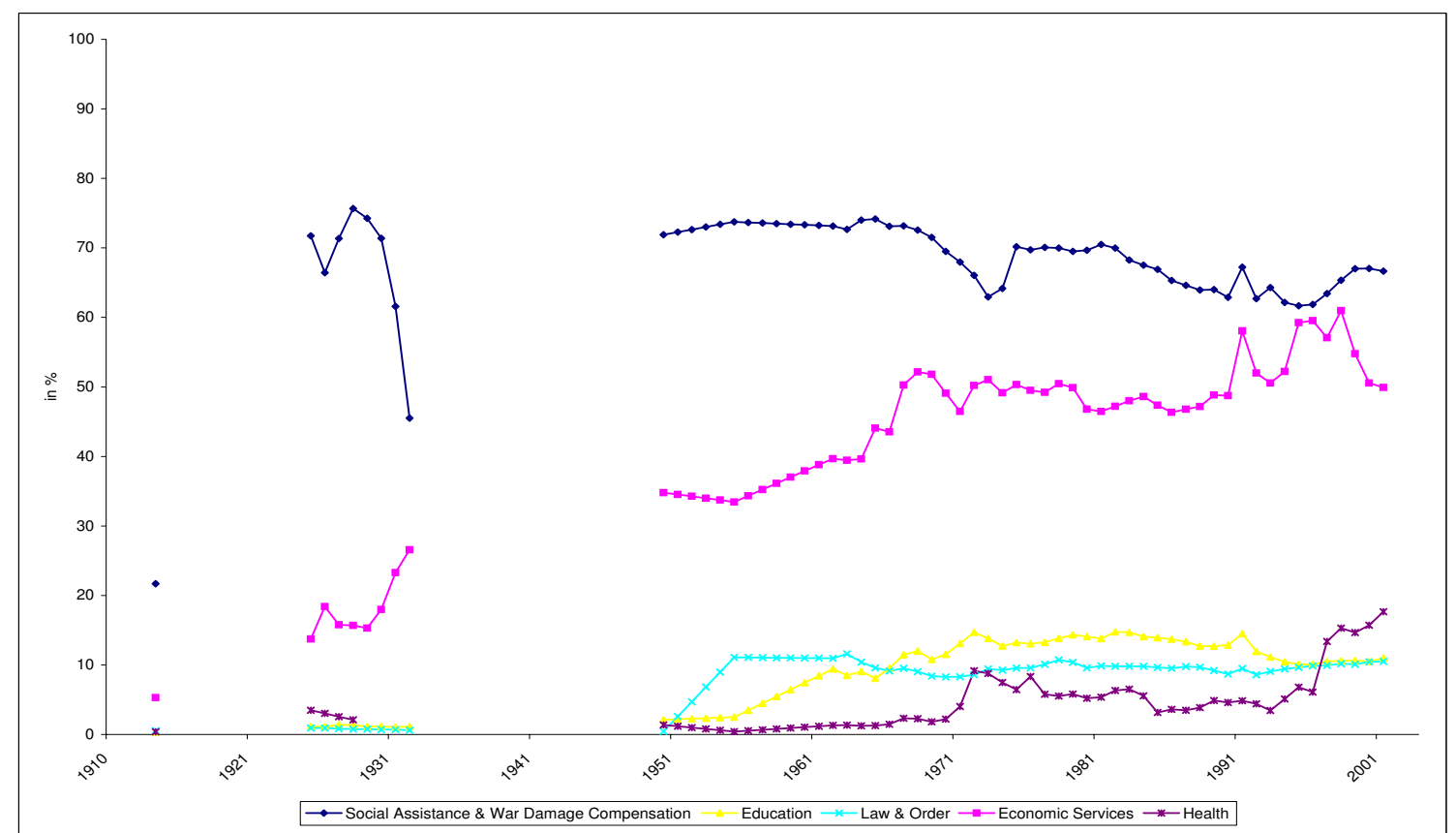

Note: Central government expenditure in \% of total public expenditure by government function, as reported in national financial statistics. See the appendix for detailed figures (Table 5) and for a breakdown by government functions.

Alternatively, with a share of $64.0 \%$, the local level was by far the most important fiscal tier regarding transport spending in 1913. According to Tilly (1997), local authorities played a significant role during the process of industrialization, especially from 1897 to 1912, by providing public infrastructure. This role was then quickly taken over by the state and, in particular, the central level. After rising to its absolute peak of $69.7 \%$ in 1929, the local level's share thus dropped to $21.3 \%$ in 1975 , until reaching $31.1 \%$ in 2001. Nonetheless, the distribution of expenditure shares between the central and the sub-central levels indicate significant joint activities in this area after 1950. This development may indicate an increasing tendency to provide uniform public services as claimed by Popitz (1927) and Peacock and Wiseman (1961).

In accordance with the constitutional assignment, apart from law \& order, the state level clearly emerged as the most important fiscal tier in charge of education and science. Particularly during the Weimar Republic, school expenditures were increasingly allocated from the local to the state level. The share of total school expenditure made at the local level thus decreased to $28.7 \%$ in 2001, representing less than half of its share in 1913. However, after World War II, the central government became increasingly involved in activities related to law \& order and universities and science, areas of original state competency. Accordingly, the central government's share in total science \& research expenditure increased from $40.7 \%$ in 1950 to $80.2 \%$ in 1982 , and decreased at $69.8 \%$ thereafter. ${ }^{39}$

Moreover, whereas expenditures on health and communal services persisted mainly in local responsibility, further tasks, like social assistance during the Weimar Republic, and housing and cultural affairs after World War II, have been transferred from the local to the central, and respectively, to the state level. As shown by previous studies, too, the disaggregated long-term trend indicates an upward shift of government functions to

\footnotetext{
${ }^{39}$ For earlier periods, Pfetsch (1974) reports a rise of the central level's percentage of expenditure on science and technology in relation to the state level by 2.6 times from $9.7 \%$ in 1871 to $24.9 \%$ in 1914 .
} 
state and central government at the expense of the local level. ${ }^{40}$

Altogether, the budgetary figures clearly support the institutional analysis in the previous section, partly indicating a secular centralization trend in Germany from 1871 to the present day. However, rather than showing a monotonous pattern, the development is characterized by stepwise increases corresponding to exogenous shocks and changes in the political system. When excluding the upward shifts caused by the wars, only the interwar period is characterized by increasing fiscal centralization. Though remaining the most important fiscal tier, the central government's share in total public expenditure and tax revenue decreased significantly after 1950, while at the same time the state government's share increased, at least in budgetary terms. Interestingly, the German reunification in 1990 which exerted an important economic and political effect, produced no significant change in the vertical government structure.

Therefore, Popitz' "law" of increasing centralization is only confirmed since the German unification in the 19th century until World War II. After 1950, a significant structural break occurred, the state level regaining importance at the expense of the local level. Only from the point of view of the local level, the development after World War II indicates a shift of competencies to upper levels of government, albeit local governments still have a higher degree of tax autonomy than state governments. This development, however, runs counter to Popitz' additional prediction that centralization occurs at the expense of the states. These results are consistent with previous studies for Germany. On the other hand, Popitz' second hypothesis concerning increasing overlap of state and central government functions seems to be confirmed for the period after 1950. However, instead of the predicted rise in policy centralization, as during the Weimar Republic, the increasing overlap resulted in a new type of "hidden" centralization consisting of joint central/state decision-making and financing. ${ }^{41}$ The descriptive analysis for Germany therefore provides no clear evidence for a general continuous and unavoidable process of government centralization.

\section{Determinants of Fiscal Decentralization after World War II}

In the following, we take a closer look at the development in Germany after World War II, which seems distinct from that during the preceding periods. For this purpose, a time series analysis is carried out to explore the factors determining the degree of public sector decentralization after 1950. The particular focus lies on the role of economic development and on the impact of economic and European integration.

\subsection{Quantitative Approach}

Two important factors may have had a significant influence on the development of the public sector since World War II. First, as mentioned above, Peacock and Wiseman (1961) suggest that the degree of centralization of the public sector tends to increase in the course of economic development and with advancing urbanization due to improvements in transport and communication and to increasing spillovers of public goods. Apart from this, demand for income redistribution and the establishment of generous welfare systems are also expected to be positively related to higher income per capita. On the other hand, empirical evidence shows that high-income countries are likely to be more decentralized. This is explained by higher real costs of decentralized structures at

\footnotetext{
${ }^{40}$ For example, Hansmeyer and Zimmermann (1984) report a significant shift of expenditure competencies from state to central government only for the areas of health and general public finances.

${ }^{41}$ See, also, Blankart (1999), and Hansmeyer (1967) with respect to this.
} 
lower stages of economic development due to scarcity of qualified government personnel, and to costs of political coordination and creation of local government institutions. ${ }^{42}$

Second, increasing trade liberalization and global and regional economic integration seem to have fostered fiscal decentralization in several European countries. Recent literature (Alesina and Spolaore, 1997) has shown that by increasing the market size and reducing political and economic transaction costs, economic integration lowers the benefits of size, thus enhancing demands for secession or regional autonomy. Political integration, too, might contribute to public sector decentralization, since the costs of supplying certain public goods now in the competency of the supranational level are reduced. On the other hand, by increasing the economic risk, economic integration is also expected to enhance the demand for interregional risk-sharing or other policies carried out by the central government, such as income redistribution. In a recent empirical panel analysis, Stegarescu (2004b) provides evidence for a significant relationship between integration at the global and at the European level, and fiscal decentralization during the last three decades, especially among OECD countries with strong preference heterogeneity.

These particular aspects are investigated in the present work for the case of Germany after World War II, drawing on a longer period of time from 1950 to 2001. ${ }^{43}$ In order to determine whether economic growth, integration or other socioeconomic factors exert a causal influence on decentralization over time, the most common method suggests regressing the degree of fiscal decentralization on lagged values of itself and of other determinants. Since no significant institutional changes occurred since 1950, the focus of the analysis lies on the effect of time-variant factors, all other things being equal.

Formally, the basic estimation relates the degree of fiscal decentralization to economic development and integration, and controls for other possible determinants of both the assignment of government functions and revenues among fiscal tiers according to the theory of fiscal federalism and the demand for public services provided either by the central or sub-central government:

$$
\begin{aligned}
\text { Decentr }_{t}=\beta_{0}+\beta_{1} \cdot \text { Decentr }_{t-1}+\beta_{2} \cdot \text { Econ }_{t-1}+\beta_{3} \cdot \text { Integ }_{t-1} & +\beta_{4} \cdot \text { Diverse }_{t-1} \\
& +\beta_{5} \cdot \text { Trend }+u_{t} .
\end{aligned}
$$

Decentr $_{t}$ denotes the degree of fiscal decentralization in period $t$, Econ $_{t-1}$, Integ $g_{t-1}$ and Diverse $e_{t-1}$ the past values of variables capturing economic development, economic and European integration, and other determinants of decentralization, respectively. ${ }^{44}$ Fiscal decentralization is measured as the share of sub-central government expenditure or revenue in total public expenditure or revenue. In order to solve the problems of spurious regressions mentioned in the literature and to account for the effect of history, the lagged value of decentralization, Decentr ${ }_{t-1}$, is included on the right-hand side of the equation, too. The dynamic behavior of series is further accounted for by the direct inclusion of a linear function of time (Trend) in the regression model. ${ }^{45}$

The hypothesis of a centralizing effect of economic development set up by Peacock and Wiseman (1961) is tested by including the natural log of real per capita income in the

\footnotetext{
${ }^{42}$ See, e.g., Oates (1972).

${ }^{43}$ Note that no continuous time series for the degree of fiscal decentralization is available before World War I and the interwar period is not only short, but also plagued with strong fluctuations.

${ }^{44}$ See the appendix for data sources and definitions of the variables.

${ }^{45}$ Granger and Newbold (1974) point to the problem of trending behavior and high autocorrelation in the residuals in analysis of macroeconomic data. In case of co-integrated series, that is series that drift together at roughly the same rate, standard significance tests are misleading, regressions typically yielding apparently significant results, even if the series are completely independent. Admittedly, the inclusion of a trend alone might not solve entirely the problem of non-stationarity if the series are co-integrated. However, differencing the series would provide no reasonable alternative either, since it would obscure information on the long-run relationship between dependent and independent variables. Also, the economic relationship is expected to be different between levels and between increments. See also Greene (2000: $778 \mathrm{f}, 789 \mathrm{f})$ with respect to this.
} 
regression. In addition to this, we control for the effect of population size and density, or alternatively, the degree of urbanization, and for other possible determinants like the dependency ratio or the rate of unemployment. In order to account for changes in the degree of fiscal decentralization related to the business cycle, the contemporaneous value of the rate of growth of real per capita income is included, too. As in Stegarescu (2004b), economic integration is captured by the degree of trade openness, whereas European integration is represented in terms of the share of EU expenditure in total public expenditure of EU member countries and, respectively, the share of EU trade in total German foreign trade.

Since our interest is in the investigation of the determinants of fiscal decentralization, we consider only the single aspect of Granger causality in one direction and refrain from running vector autoregressive regressions. ${ }^{46}$ As already noted by Pryor (1968), the results of time series and of cross-section analyses of the determinants of fiscal decentralization may differ considerably. First, due to specific institutional factors, the degree of variation in decentralization across countries at one or even different points in time is generally higher than for single nations over time. Second, the determinants of the composition of public expenditures, such as technology, population or income structures are expected to be different for both dimensions. Whereas, for example, cross-country variation in population size is rather expected to reflect potential economies of scale in the provision of public goods, variation over time might represent changing demand patterns. Also, time series analyses for single countries have the advantage that statistical and fiscal definitions are mostly consistent. Apart from this, one has to take into account that issues of multicollinearity and serial correlation are more severe in time series than in panel analysis.

\subsection{Results}

Table 2 shows the results from OLS regressions of the degree of expenditure decentralization (excluding social security) using different specifications. ${ }^{47}$ Checking for influential observations, the year 1991 has been excluded from the sample due to the distortionary statistical effect of reunification. In addition to this, dummy variables are included to control for distinct developments in the postwar period (1950-55) due to reconstruction and for the territorial and structural changes caused by reunification in 1990. Due to severe problems of multicollinearity encountered in time series analysis, additional variables are included only insofar as they contribute to the goodness of fit of the regression. The estimation takes account of just one lag, since the inclusion of higher order lags was rejected on grounds of the Akaike criterion (AIC). Note that the Breusch-Godfrey (BG) tests allowing for 1 or 2 lags mostly do not indicate the presence of residual autocorrelation. The inclusion of quadratic or cubic trends did not alter the results of the estimations and did not improve the goodness of fit of the regression.

The estimates are clearly consistent with the previous descriptive analysis, running counter the prediction of Peacock and Wiseman (1961) concerning increasing centralization in the course of economic development. At least for the period after 1950, per capita income is shown to have a positive impact on the degree of expenditure decentralization in Germany, even controlling for a trend and the possible effects of postwar reconstruction and later reunification. In terms of elasticity, an increase in real per capita income by one percent raises the degree of decentralization by 0.4 percent. ${ }^{48}$ This result is robust

\footnotetext{
${ }^{46}$ See Granger (1969). In this regard, the equation is a reduced form which neglects the contemporaneous relationship between the variables.

${ }^{47}$ Social security is excluded, since no consistent data are available for the period before 1974 .

${ }^{48}$ The standard error is 0.114 . The elasticity has been calculated by running a log-linear regression, the results are available upon request.
} 
Table 2: OLS estimates of fiscal decentralization, total self-financed expenditure (excl. social security), Germany, 1950-2001

\begin{tabular}{|c|c|c|c|c|c|c|}
\hline & \multicolumn{6}{|c|}{ Dep. var.: Degree of expenditure decentralization } \\
\hline & $(1)$ & $(2)$ & $(3)$ & $(4)$ & $(5)$ & $(6)$ \\
\hline Decentr $_{t-1}$ & $\begin{array}{l}.440^{\star \star \star} \\
(.101)\end{array}$ & $\begin{array}{l}.484^{\star \star \star} \\
(.152)\end{array}$ & $\begin{array}{l}.488^{\star \star \star} \\
(.104)\end{array}$ & $\begin{array}{l}.378^{\star \star \star} \\
(.103)\end{array}$ & $\begin{array}{l}.453^{\star \star \star} \\
(.118)\end{array}$ & $\begin{array}{l}.422^{\star \star \star} \\
(.098)\end{array}$ \\
\hline Per capita income in-1 & $\begin{array}{l}.267^{\star \star \star} \\
(.047)\end{array}$ & $\begin{array}{l}.268^{\star \star \star} \\
(.084)\end{array}$ & $\begin{array}{l}.279^{\star \star \star} \\
(.047)\end{array}$ & $\begin{array}{l}.260^{\star \star \star} \\
(.046)\end{array}$ & $\begin{array}{l}.268^{\star \star \star} \\
(.048)\end{array}$ & $\begin{array}{l}.312^{\star \star \star} \\
(.051)\end{array}$ \\
\hline Population $_{t-1}$ & & $\begin{array}{l}-.069 \\
(.113)\end{array}$ & & & & \\
\hline Density $_{t-1}$ & $\begin{array}{l}-.371^{\star \star \star} \\
(.119)\end{array}$ & & $\begin{array}{l}-.321^{\star \star} \\
(.120)\end{array}$ & $\begin{array}{l}-.392^{\star \star \star} \\
(.116)\end{array}$ & $\begin{array}{l}-.356^{\star \star} \\
(.138)\end{array}$ & $\begin{array}{l}-.774^{\star \star \star} \\
(.233)\end{array}$ \\
\hline Urbanization $_{t-1}$ & & $\begin{array}{l}-1.904^{\star \star \star} \\
(.637)\end{array}$ & & & & \\
\hline Growth rate r $_{t}$ & $\begin{array}{l}.279^{\star \star \star} \\
(.073)\end{array}$ & $\begin{array}{l}.224^{\star \star} \\
(.096)\end{array}$ & $\begin{array}{l}.295^{\star \star \star} \\
(.072)\end{array}$ & $\begin{array}{l}.257^{\star \star \star} \\
(.072)\end{array}$ & $\begin{array}{l}.281^{\star \star \star} \\
(.075)\end{array}$ & $\begin{array}{l}.274^{\star \star \star} \\
(.071)\end{array}$ \\
\hline Dependency ratio t-1 $_{1}$ & & & & & & $\begin{array}{l}.594^{\star} \\
(.298)\end{array}$ \\
\hline Trade openness $s_{t-1}$ & & & $\begin{array}{l}.074 \\
(.045)\end{array}$ & & & \\
\hline$E U \exp _{\cdot t-1}$ & & & & $\begin{array}{l}.013^{\star} \\
(.007)\end{array}$ & & \\
\hline$E U$ trade $_{t-1}$ & & & & & $\begin{array}{l}-.021 \\
(.095)\end{array}$ & \\
\hline Reunification & $\begin{array}{l}-.003 \\
(.011)\end{array}$ & $\begin{array}{l}.046 \\
(.037)\end{array}$ & $\begin{array}{l}.017 \\
(.016)\end{array}$ & $\begin{array}{l}-.004 \\
(.011)\end{array}$ & $\begin{array}{l}-.000 \\
(.017)\end{array}$ & $\begin{array}{l}-.044^{\star} \\
(.023)\end{array}$ \\
\hline Postwar & $\begin{array}{l}.041^{\star \star \star} \\
(.010)\end{array}$ & & $\begin{array}{l}.046^{\star \star \star} \\
(.010)\end{array}$ & $\begin{array}{l}.033^{\star \star \star} \\
(.010)\end{array}$ & $\begin{array}{l}.042^{\star \star \star} \\
(.012)\end{array}$ & $\begin{array}{l}.037^{\star \star \star} \\
(.010)\end{array}$ \\
\hline Trend & $\begin{array}{l}-.005^{\star \star \star} \\
(.001)\end{array}$ & & $\begin{array}{l}-.006^{\star \star \star} \\
(.001)\end{array}$ & $\begin{array}{l}-.006^{\star \star \star} \\
(.001)\end{array}$ & $\begin{array}{l}-.005^{\star \star \star} \\
(.001)\end{array}$ & $\begin{array}{l}-.005^{\star \star \star} \\
(.001)\end{array}$ \\
\hline No. obs. & 49 & 39 & 49 & 49 & 49 & 49 \\
\hline $\mathrm{R}^{2}$ & .899 & .838 & .906 & .908 & .900 & .909 \\
\hline adj. $R^{2}$ & .882 & .808 & .887 & .889 & .880 & .890 \\
\hline $\mathrm{BG}(1)$ & 2.199 & 2.184 & 1.410 & 1.433 & 2.295 & 1.420 \\
\hline $\mathrm{BG}(2)$ & 2.283 & 2.227 & 1.417 & 1.439 & 2.427 & 1.425 \\
\hline
\end{tabular}

Note: Standard errors are in brackets. $* * * * *$, and $*$ indicate significance at $1 \%, 5 \%$ and $10 \%$ levels, respectively. Degree of expenditure decentralization: total expenditure of sub-central government excluding transfers received from central government (self-financed expenditure) in total public expenditure of consolidated general government.

to the exclusion of the trend variable or of other variables, such as population density. Moreover, F-tests for joint significance of 1 and 2 lags strongly support this causal relationship at the 0.3 percent level.

On the other hand, increasing population density or urbanization are associated with higher centralization. This result may be explained by the fact that, whereas rapidly increasing urbanization and technological progress actually boosted municipal governments' investments in local infrastructure at the end of the 19th century, once the largescale construction of the basic infrastructure had been accomplished, the advance of urbanization after 1950 generated other pressures instead, particularly demands for social assistance. ${ }^{49}$ The effects of both population density and urbanization are, however, quite sensitive to the inclusion of per capita income, being plagued by problems of multicollinearity.

Apart from the lagged degree of decentralization, which points to a significant role of

\footnotetext{
${ }^{49}$ Note that time series for the degree of urbanization are only available since 1960. Also, due to very high collinearity, urbanization is included in the regression without the trend variable.
} 
history, the estimates also indicate a significant and robust influence of business cycles. Accordingly, higher economic growth rates seem to increase sub-central government expenditures to a larger extent than central government expenditures. An increase in the share of population aged below 15 or above 64 , the dependency rate, is also found to have a weak positive effect on the degree of decentralization. Note, also, that both the trend variable and the dummy variable for the postwar period yield significant signs, whereas no distinct pattern can be made out for the period after reunification. Other possible determinants, such as the rate of unemployment, the share of persons employed in agriculture, national elections or the share of leftist parties in government had no significant effects (not shown).

With respect to the effect of integration, only political integration in the EU as depicted by the level of EU expenditure exerts a weakly significant decentralizing effect. Ftests, however, cannot reject the hypothesis of no effect of both economic and European integration. When excluding the trend variable or per capita income, the time pathes of which are highly correlated with those of the integration variables, the results of the regression remain unchanged.

The time series analysis for Germany therefore mostly supports the results of the panel analysis for OECD countries in Stegarescu (2004b) with respect to the role of economic development, urbanization and integration. There, economic and European integration were shown to have fostered fiscal decentralization particularly in case of strong preference heterogeneity and missing participation of subnational governments in central policymaking which prevents the establishment of tax cartels. Since both conditions are not met in the case of Germany, it is not surprising that integration plays no significant role here. Despite this evidence, a mutual causal relationship between economic development and integration, and changes in the vertical assignment of public expenditures cannot be completely ruled out in the present analysis.

To test for the robustness of the results, alternative regressions have been run for the degree of decentralization of public expenditure excluding defense (not shown), for certain government functions (Tables 6 and 7 in the appendix) and for total tax revenues (Table 8 in the appendix). The results are quite similar, particularly concerning the effect of economic development. According to the descriptive analysis provided above, the central government's share in public expenditures on economic services such as transport infrastructure, which are supposed to play an important role in locational competition in an integrating world economy, increased considerably since 1950. The regression analysis, however, detects a highly significant decentralizing effect of economic integration only for public expenditures related to economic development and state-owned enterprises (other economic services).

In interpreting these results, one has to take again into account the limitations related to the measurement of fiscal decentralization by means of unadjusted budgetary data. Apart from non-quantifiable legislative or regulatory activities, the extent of subnational discretion in decisions regarding public expenditures and taxation is not adequately taken into account in the present analysis. Since no significant changes in the distribution of legislative powers occurred during this time, the quantitative analysis mainly explains variations in the rates of growth of each fiscal tier's activities and revenues.

\section{$5 \quad$ Summary and Conclusions}

The purpose of the present work was to investigate the long-term trend and the underlying determinants of public sector centralization in Germany from the creation of a unified state in 1871 to the present day. Both the institutional and the quantitative 
review of the German history in fact document a significant growth of the public sector in line with Wagner's "law", together with a stepwise increase in the role of the central government, particularly due to the expansion of the welfare state.

However, similarly to earlier studies for Germany and for other countries, there is no clear support for a continuous and unavoidable process of centralization in the public sector as suggested by Popitz (1927), but rather for some distinct developments caused by the distortionary effects of wars and regime changes. The rise of the central government since 1871 seems to have come to an end in the aftermath of World War II, being replaced by a new type of "hidden" centralization (Blankart, 1999), which is characterized by complex interconnections between the central and the state levels. A significant difference consists in the fact that whereas prior to 1950 competencies have been transferred particularly from the state to the central level, after 1950 the upward shift occurred from local to state and central government. It rests unclear which tendency would have dominated in the public sector without the event of significant exogenous shocks like the two world wars or drastic changes in the political system. Therefore, Popitz' claims have to be assessed against the historical and political background specific to the interwar period.

The historical analysis, however, sheds some light on the role of institutional rules of decision-making, supporting the collusion hypothesis of Brennan and Buchanan (1980). Accordingly, only the specific institutional set-up after World War II, which provided for equal participation of the state level in decision-making concerning the distribution of revenues, as well as for the allocation of concurrent powers to the central government, enabled the creation of revenue cartels between the state and the central levels aimed at mitigating fiscal competition.

In order to explain the different development noticed after World War II and to test the validity of previous international studies for the specific German case, a time series regression analysis of the determinants of fiscal decentralization was run for the period 1950 to 2001. The results mostly support a recent panel analysis for OECD countries, indicating a significant decentralizing effect of per capita income growth during this time, whereas increasing population density and urbanization were associated with higher centralization. On the other hand, in contrast to other European countries, there is no clear evidence for a causal relationship between economic and European integration and fiscal decentralization in the case of Germany. This is probably due to weak preference heterogeneity and the implication of subnational governments in central policymaking.

In the end, these findings suggest that public sector growth and centralization are not inevitable features of government following certain laws of nature. Therefore, this analysis allows no clear forecast with respect to the future allocation of functions and revenues across levels of government in Germany, which certainly depends on the advance of European integration and on changes in the areas of public sector activity. In international comparison there are indeed a number of indicators for a diminishing role of the state in a global economy. Government functions are increasingly shifted to the private sector, for example in terms of privatizations of state enterprises or the emergence of publicprivate partnerships. However, whether these developments actually lead to increased centralization or decentralization of the public sector, is not a priori clear.

In addition, as shown by the case of Germany, vertical government structures in federal countries barely change in the course of time, except owing to strong exogenous shocks. Apart from this, the long-term development is crucially influenced by country-specific institutions and preferences. Nonetheless, recent developments, such as the reform of the welfare state and reduced national expenditures for defense indicate a decline in traditional areas of central government activity, together with a loss of importance of national factors of location with advancing globalization and the transfer of powers to supranational authorities. 


\section{Appendix}

\section{Tables and Figures}

Figure 5: Allocation of total public expenditure (including social security) by fiscal tiers, Germany, 1881-2001

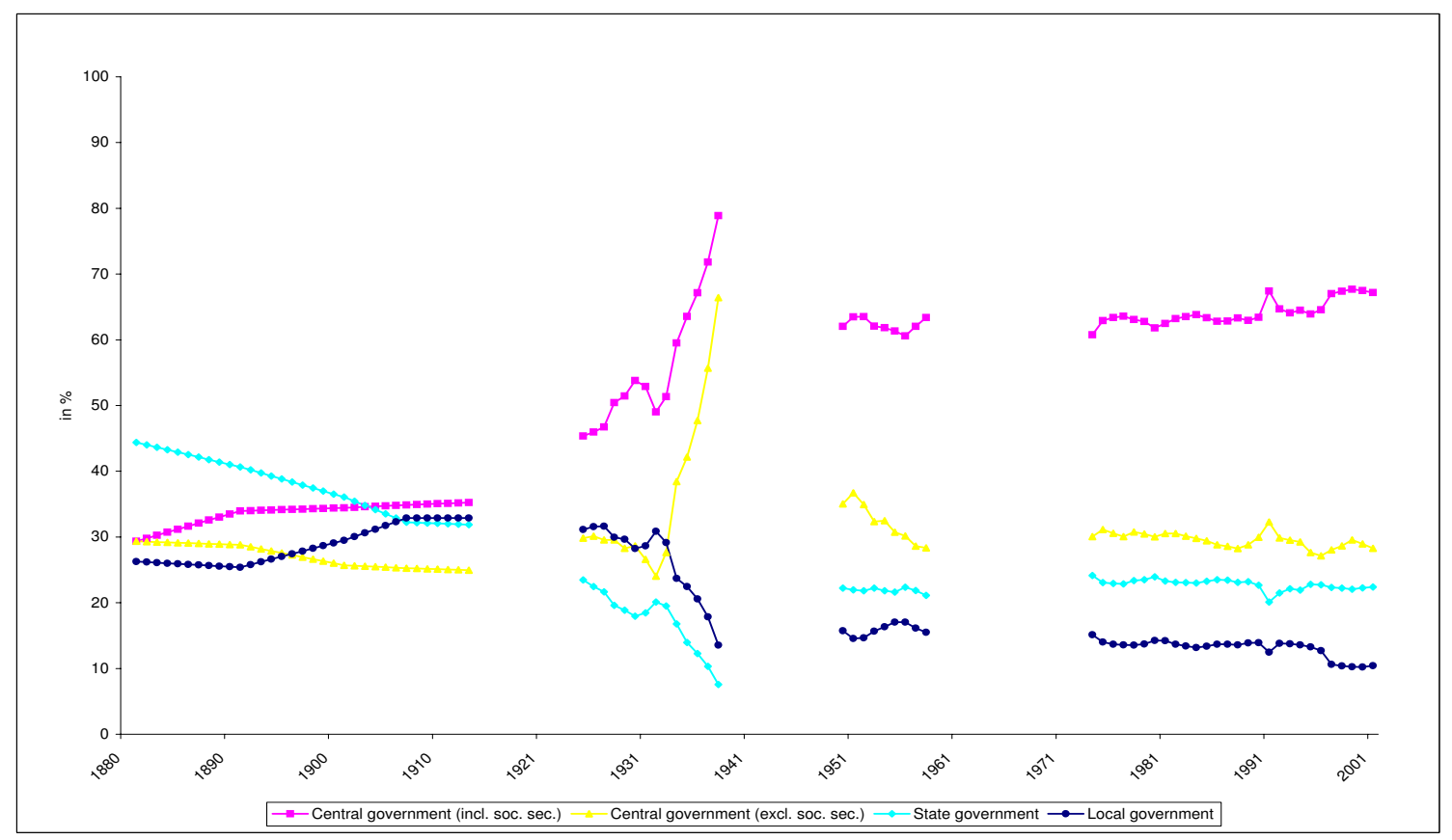

Note: Public expenditure by level of government in \% of total expenditure of consolidated government, including social security, and excluding payments to the EU. No social security figures are available for the period 1959-1973. Due to different expenditure definitions, the time series 1881-1959 and 1974-2001 are not strictly comparable. Source: see below.

Table 3: Allocation of public expenditure by level of government, Germany, 1881-2001

\begin{tabular}{|c|c|c|c|c|c|c|c|c|}
\hline & \multicolumn{4}{|c|}{ Public expenditure (incl. soc. sec.) } & \multicolumn{4}{|c|}{ Public expenditure (excl. soc. sec.) } \\
\hline & $\begin{array}{c}\text { Total }^{a} \\
(\% \text { NNP })\end{array}$ & $\begin{array}{c}\text { Central } \\
\text { (share) }\end{array}$ & $\begin{array}{c}\text { State } \\
\text { (share) }\end{array}$ & $\begin{array}{c}\text { Local } \\
\text { (share) }\end{array}$ & $\begin{array}{c}\text { Total }^{a} \\
(\% \text { NNP })\end{array}$ & $\begin{array}{l}\text { Central } \\
\text { (share) }\end{array}$ & $\begin{array}{c}\text { State } \\
\text { (share) }\end{array}$ & $\begin{array}{c}\text { Local } \\
\text { (share) }\end{array}$ \\
\hline 1881 & 10.6 & 29.3 & 44.4 & 26.3 & 10.6 & 29.3 & 44.4 & 26.3 \\
\hline 1891 & 12.3 & 34.0 & 40.7 & 25.4 & 12.2 & 30.4 & 42.9 & 26.8 \\
\hline 1901 & 13.4 & 34.4 & 36.1 & 29.5 & 13.3 & 28.2 & 39.5 & 32.3 \\
\hline 1907 & 13.5 & 34.9 & 32.2 & 32.9 & 13.4 & 28.0 & 35.7 & 36.4 \\
\hline 1913 & 14.8 & 35.2 & 31.9 & 32.9 & 14.7 & 27.8 & 35.5 & 36.7 \\
\hline $1925-1932$ & 25.0 & 49.5 & 20.3 & 30.2 & 24.7 & 38.8 & 23.9 & 37.4 \\
\hline 1933-1938 & 30.3 & 65.4 & 13.4 & 21.2 & 30.1 & 57.0 & 14.8 & 28.2 \\
\hline $1950-1955$ & 37.0 & 62.4 & 21.9 & 15.7 & 26.1 & 51.3 & 29.0 & 19.6 \\
\hline 1985-1990 & 52.4 & 63.1 & 23.2 & 13.7 & 34.6 & 44.0 & 35.2 & 20.8 \\
\hline $1996-2001$ & 57.9 & 66.9 & 22.3 & 10.8 & 36.3 & 46.2 & 36.3 & 17.5 \\
\hline
\end{tabular}

Note: Public expenditure by level of government, in $\%$ of consolidated public expenditure (excluding EU payments) according to financial statistics, including or excluding social security; period averages. ${ }^{a}$ public expenditure of consolidated general government (excluding EU payments) according to national income statistics, including or excluding social security, in $\%$ of net national product at market prices (note that social security expenditures are understated before 1950). Source: see below. 
Table 4: Allocation of tax revenue by level of government, Germany, 1881-2001

\begin{tabular}{lccc}
\hline \hline & \multicolumn{3}{l}{ Tax revenue } \\
& $\begin{array}{c}\text { Central } \\
\text { (share) }\end{array}$ & $\begin{array}{c}\text { State } \\
\text { (share) }\end{array}$ & $\begin{array}{c}\text { Local } \\
\text { (share) }\end{array}$ \\
\hline 1881 & 39.0 & 35.1 & 25.9 \\
1891 & 48.5 & 26.5 & 25.0 \\
1901 & 44.3 & 25.6 & 30.1 \\
1907 & 44.3 & 23.6 & 32.1 \\
1913 & 40.3 & 22.6 & 37.2 \\
$1925-1932$ & 46.7 & 23.1 & 30.3 \\
$1933-1938$ & 61.4 & 14.8 & 23.8 \\
$1950-1955$ & 61.1 & 27.3 & 11.6 \\
$1985-1990$ & 48.7 & 38.0 & 13.4 \\
$1996-2001$ & 48.8 & 39.6 & 11.6 \\
\hline \hline
\end{tabular}

Note: Tax revenue by level of government, in \% of consolidated tax revenue (excluding social security and EU payments) according to financial statistics; period averages. Source: see below.

Figure 6: Composition of central government expenditure by government function, Germany, 1881-2001

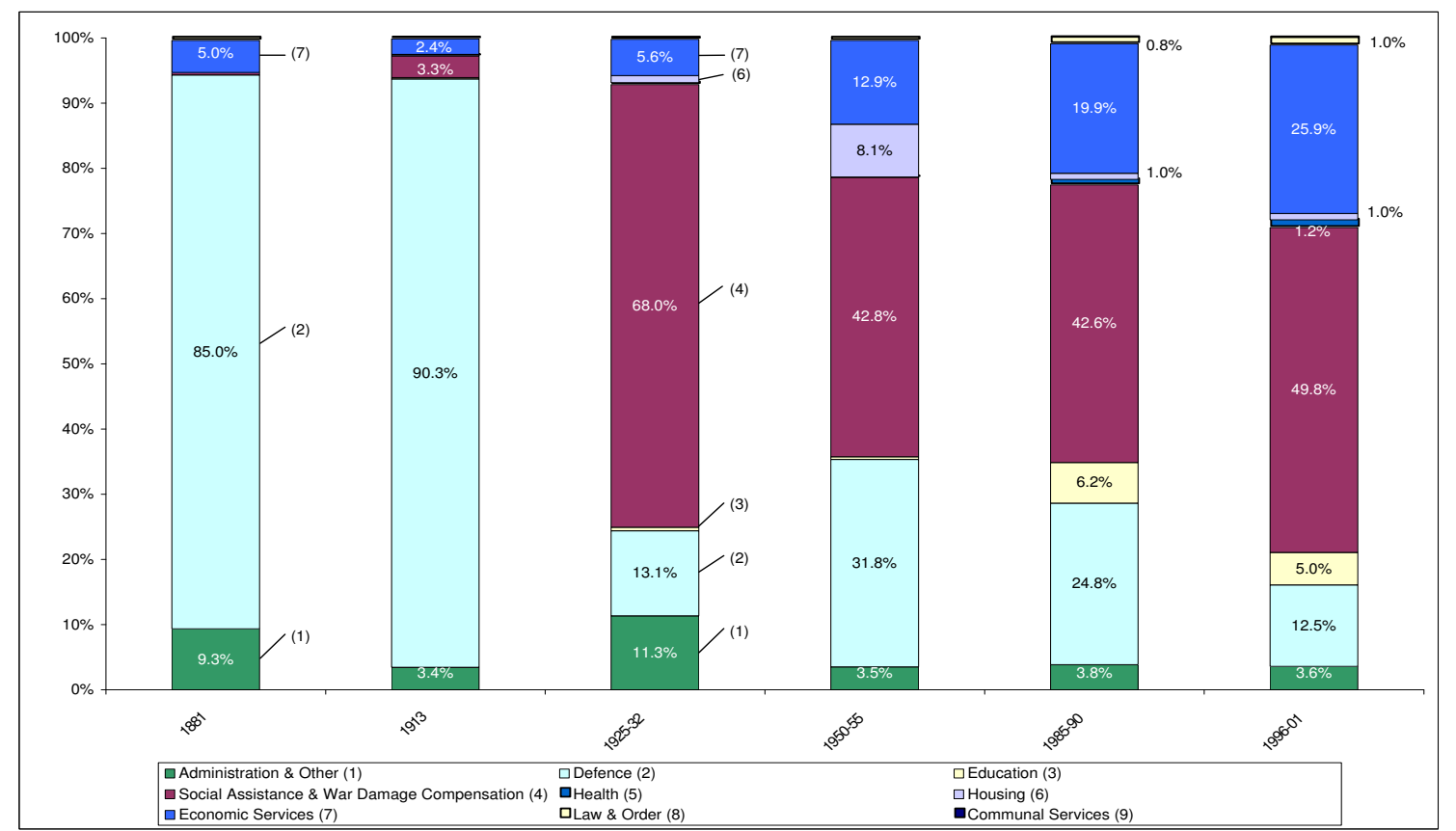

Note: Expenditure by government function in \% of total central government expenditure (excluding social security), as reported in national financial statistics; period averages. Debt service and financial transfers are excluded, too. Source: see below. 
Figure 7: Composition of state government expenditure by government function, Germany, 1913-2001

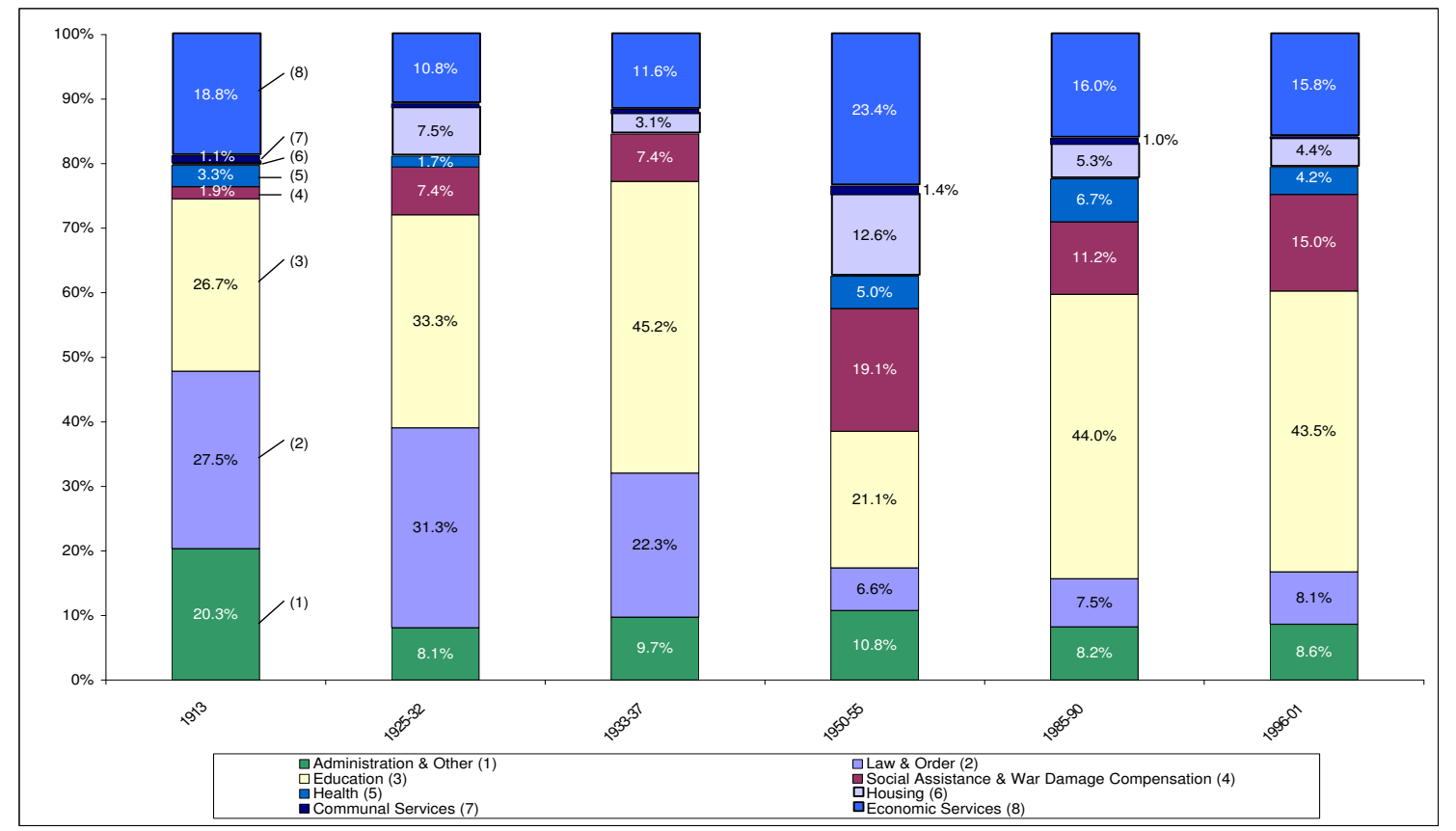

Note: Expenditure by government function in \% of total state government expenditure, as reported in national financial statistics; period averages. Debt service and financial transfers are excluded. Source: see below.

Figure 8: Composition of local government expenditure by government function, Germany, 1913-2001

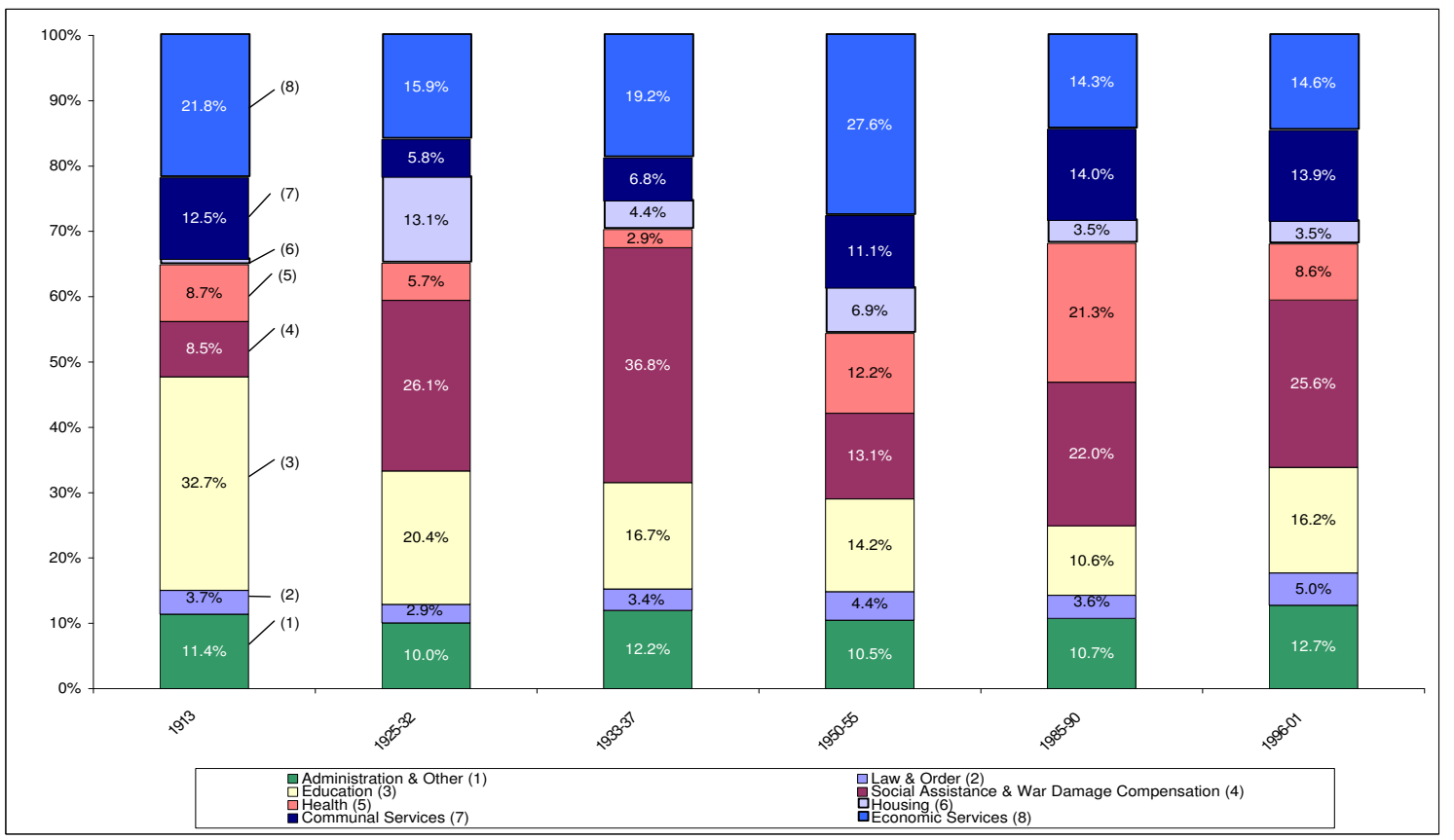

Note: Expenditure by government function in \% of total local government expenditure, as reported in national financial statistics; period averages. Debt service and financial transfers are excluded. Source: see below. 
Table 5: Allocation of public expenditure by government function and level of government, Germany, 1913-2001

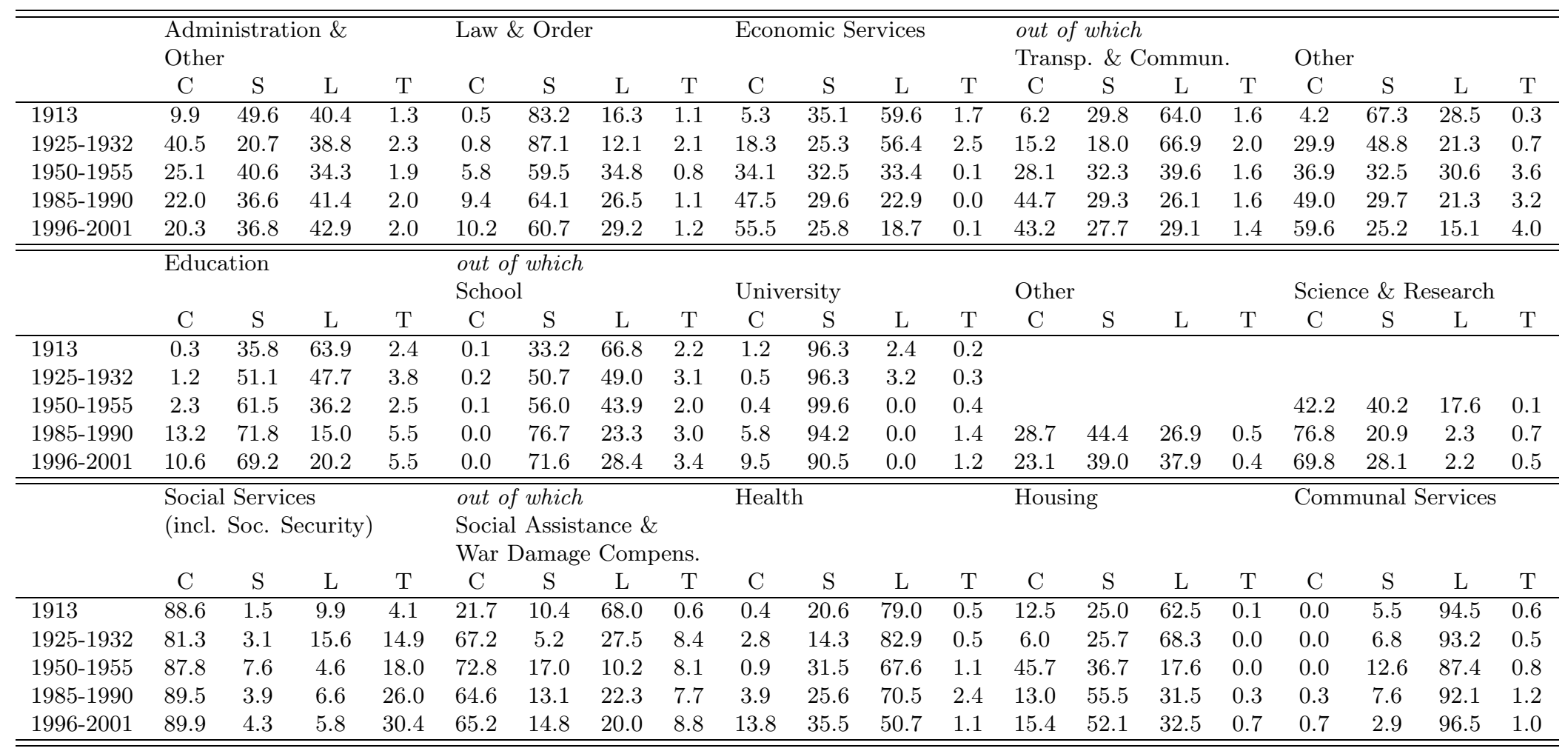

Note: Public expenditure of central (C), state $(\mathrm{S})$ and local $(\mathrm{L})$ government in $\%$ of total public expenditure, and total (T) public expenditure in \% of net national product, by government function, as reported in financial statistics; period averages. Defense, social security, debt service and financial transfers are not considered. Source: see below. 
Table 6: OLS estimates of fiscal decentralization, self-financed expenditure on other economic services, Germany, 1950-2001

\begin{tabular}{|c|c|c|c|c|c|}
\hline & $\begin{array}{l}\text { Dep. var.: } \\
\text { (1) }\end{array}$ & $\begin{array}{l}\text { Degree o } \\
(2)\end{array}$ & $\begin{array}{l}\text { expend. } \\
(3)\end{array}$ & $\begin{array}{l}\text { lecentr. } \\
\text { (4) }\end{array}$ & (5) \\
\hline Decentr $_{t-1}$ & $\begin{array}{l}.468^{\star \star \star} \\
(.119)\end{array}$ & $\begin{array}{l}.478^{\star \star \star} \\
(.119)\end{array}$ & $\begin{array}{l}.416^{\star \star \star} \\
(.088)\end{array}$ & $\begin{array}{l}.524^{\star \star \star} \\
(.113)\end{array}$ & $\begin{array}{l}.463^{\star \star \star} \\
(.113)\end{array}$ \\
\hline Per capita income $_{t-1}$ & $\begin{array}{l}.181 \\
(.147)\end{array}$ & $\begin{array}{l}.330 \\
(.265)\end{array}$ & $\begin{array}{l}.252^{\star} \\
(.134)\end{array}$ & $\begin{array}{l}.148 \\
(.121)\end{array}$ & $\begin{array}{l}.190 \\
(.142)\end{array}$ \\
\hline Population $_{t-1}$ & & $\begin{array}{l}-1.009^{\star \star} \\
(.432)\end{array}$ & & & \\
\hline Density $_{t-1}$ & $\begin{array}{l}-1.072^{\star \star} \\
(.483)\end{array}$ & & $\begin{array}{l}-.978^{\star \star} \\
(.364)\end{array}$ & $\begin{array}{l}-.993^{\star \star} \\
(.421)\end{array}$ & $\begin{array}{l}-1.005^{\star} \\
(.546)\end{array}$ \\
\hline Urbanization $_{t-1}$ & & $\begin{array}{l}-2.053 \\
(1.990)\end{array}$ & & & \\
\hline Growth rate $_{t}$ & $\begin{array}{l}-.046 \\
(.118)\end{array}$ & $\begin{array}{l}-.049 \\
(.241)\end{array}$ & $\begin{array}{l}-.034 \\
(.103)\end{array}$ & $\begin{array}{l}-.051 \\
(.112)\end{array}$ & $\begin{array}{l}-.052 \\
(.117)\end{array}$ \\
\hline Trade openness $s_{-1}$ & & & $\begin{array}{l}.303^{\star \star \star} \\
(.099)\end{array}$ & & \\
\hline$E U$ exp.t-1 & & & & $\begin{array}{l}.023 \\
(.014)\end{array}$ & \\
\hline$E U$ trade $_{t-1}$ & & & & & $\begin{array}{l}-.109 \\
(.187)\end{array}$ \\
\hline Reunification & $\begin{array}{l}-.127^{\star \star \star} \\
(.044)\end{array}$ & $\begin{array}{l}.265^{\star} \\
(.137)\end{array}$ & $\begin{array}{l}-.062^{\star \star} \\
(.028)\end{array}$ & $\begin{array}{l}-.112^{\star \star \star} \\
(.042)\end{array}$ & $\begin{array}{l}-.116^{\star \star} \\
(.055)\end{array}$ \\
\hline Postwar & $\begin{array}{l}.017 \\
(.018)\end{array}$ & & $\begin{array}{l}.039^{\star} \\
(.020)\end{array}$ & $\begin{array}{l}.003 \\
(.013)\end{array}$ & $\begin{array}{l}.024 \\
(.017)\end{array}$ \\
\hline Trend & $\begin{array}{l}-.002 \\
(.003)\end{array}$ & & $\begin{array}{l}-.008^{\star \star} \\
(.003)\end{array}$ & $\begin{array}{l}-.003 \\
(.003)\end{array}$ & $\begin{array}{l}-.002 \\
(.003)\end{array}$ \\
\hline No. obs. & 49 & 39 & 49 & 49 & 49 \\
\hline $\mathrm{R}^{2}$ & .897 & .787 & .914 & .901 & .897 \\
\hline adj. $R^{2}$ & .879 & .747 & .897 & .881 & .877 \\
\hline $\mathrm{BG}(1)$ & 7.123 & 3.743 & 0.699 & 6.031 & 6.148 \\
\hline$B G(2)$ & 7.580 & 4.071 & 1.084 & 6.504 & 6.388 \\
\hline
\end{tabular}

Note: Due to serial correlation, Newey-West heteroscedasticity and autocorrelation consistent standard errors $(\mathrm{L}=3)$ are reported in brackets. ${ }^{* * *},{ }^{* *}$, and $*$ indicate significance at $1 \%, 5 \%$ and $10 \%$ levels, respectively. 
Table 7: OLS estimates of fiscal decentralization, self-financed expenditure on transport and communication, Germany, 1950-2001

\begin{tabular}{|c|c|c|c|c|c|}
\hline & $\begin{array}{l}\text { Dep. var } \\
\text { (1) }\end{array}$ & $\begin{array}{l}\text { Degree } \\
(2)\end{array}$ & $\begin{array}{l}\text { expend. } \\
(3)\end{array}$ & $\begin{array}{l}\text { lecentr. } \\
\text { (4) }\end{array}$ & $(5)$ \\
\hline Decentr $_{t-1}$ & $\begin{array}{l}.632^{\star \star \star} \\
(.115)\end{array}$ & $\begin{array}{l}.651^{\star \star \star} \\
(.114)\end{array}$ & $\begin{array}{l}.632^{\star \star \star} \\
(.119)\end{array}$ & $\begin{array}{l}.651^{\star \star \star} \\
(.107)\end{array}$ & $\begin{array}{l}.624^{\star \star \star} \\
(.122)\end{array}$ \\
\hline Per capita income $_{t-1}$ & $\begin{array}{l}.126^{\star \star} \\
(.061)\end{array}$ & $\begin{array}{l}.214^{\star} \\
(.112)\end{array}$ & $\begin{array}{l}.126^{\star \star} \\
(.062)\end{array}$ & $\begin{array}{l}.123^{\star \star} \\
(.060)\end{array}$ & $\begin{array}{l}.127^{\star \star} \\
(.060)\end{array}$ \\
\hline Population $_{t-1}$ & & $\begin{array}{l}-.824^{\star \star \star} \\
(.222)\end{array}$ & & & \\
\hline Density $_{t-1}$ & $\begin{array}{l}-.764^{\star \star \star} \\
(.245)\end{array}$ & & $\begin{array}{l}-.763^{\star \star \star} \\
(.244)\end{array}$ & $\begin{array}{l}-.750^{\star \star \star} \\
(.234)\end{array}$ & $\begin{array}{l}-.752^{\star \star \star} \\
(.245)\end{array}$ \\
\hline Urbanization $_{t-1}$ & & $\begin{array}{l}-1.296 \\
(.855)\end{array}$ & & & \\
\hline Growth rate $_{t}$ & $\begin{array}{l}.192 \\
(.144)\end{array}$ & $\begin{array}{l}.391^{\star} \\
(.202)\end{array}$ & $\begin{array}{l}.192 \\
(.147)\end{array}$ & $\begin{array}{l}.191 \\
(.139)\end{array}$ & $\begin{array}{l}.189 \\
(.144)\end{array}$ \\
\hline Trade openness $s_{t-1}$ & & & $\begin{array}{l}.003 \\
(.043)\end{array}$ & & \\
\hline$E U$ exp.t-1 & & & & $\begin{array}{l}.006 \\
(.007)\end{array}$ & \\
\hline$E U$ trade $_{t-1}$ & & & & & $\begin{array}{l}-.030 \\
(.080)\end{array}$ \\
\hline Reunification & $\begin{array}{l}-.042^{\star \star \star} \\
(.015)\end{array}$ & $\begin{array}{l}.263^{\star \star \star} \\
(.072)\end{array}$ & $\begin{array}{l}-.042^{\star \star \star} \\
(.013)\end{array}$ & $\begin{array}{l}-.040^{\star \star \star} \\
(.014)\end{array}$ & $\begin{array}{l}-.039^{\star \star \star} \\
(.014)\end{array}$ \\
\hline Postwar & $\begin{array}{l}.011 \\
(.008)\end{array}$ & & $\begin{array}{l}.011 \\
(.007)\end{array}$ & $\begin{array}{l}.009 \\
(.009)\end{array}$ & $\begin{array}{l}.012^{\star} \\
(.007)\end{array}$ \\
\hline Trend & $\begin{array}{l}-.002 \\
(.001)\end{array}$ & & $\begin{array}{l}-.002 \\
(.001)\end{array}$ & $\begin{array}{l}-.002 \\
(.001)\end{array}$ & $\begin{array}{l}-.002 \\
(.001)\end{array}$ \\
\hline No. obs. & 49 & 39 & 49 & 49 & 49 \\
\hline $\mathrm{R}^{2}$ & .962 & .871 & .962 & .962 & .962 \\
\hline adj. $R^{2}$ & .955 & .847 & .954 & .955 & .954 \\
\hline $\mathrm{BG}(1)$ & 3.228 & 5.294 & 3.377 & 3.706 & 3.258 \\
\hline $\mathrm{BG}(2)$ & 4.927 & 6.861 & 5.614 & 5.150 & 5.167 \\
\hline
\end{tabular}

Note: Due to serial correlation, Newey-West heteroscedasticity and autocorrelation consistent standard errors $(\mathrm{L}=3)$ are reported in brackets. ${ }^{* * *},{ }^{* *}$, and $*$ indicate significance at $1 \%, 5 \%$ and $10 \%$ levels, respectively. 
Table 8: OLS estimates of fiscal decentralization, total tax revenue, Germany, 1950-2001

\begin{tabular}{|c|c|c|c|c|c|c|}
\hline & \multicolumn{6}{|c|}{ Dep. var.: Degree of tax decentralization } \\
\hline & (1) & (2) & (3) & (4) & $(5)$ & (6) \\
\hline Decentr $_{t-1}$ & $\begin{array}{l}.510^{\star \star \star} \\
(.130)\end{array}$ & $\begin{array}{l}.743^{\star \star \star} \\
(.081)\end{array}$ & $\begin{array}{l}.523^{\star \star \star} \\
(.115)\end{array}$ & $\begin{array}{l}.512^{\star \star \star} \\
(.135)\end{array}$ & $\begin{array}{l}.516^{\star \star \star} \\
(.107)\end{array}$ & $\begin{array}{l}.471^{\star \star \star} \\
(.110)\end{array}$ \\
\hline Per capita income in-1 $_{1}$ & $\begin{array}{l}.048 \\
(.034)\end{array}$ & $\begin{array}{l}.056 \\
(.044)\end{array}$ & $\begin{array}{l}.055 \\
(.034)\end{array}$ & $\begin{array}{l}.046 \\
(.035)\end{array}$ & $\begin{array}{l}.053 \\
(.035)\end{array}$ & $\begin{array}{l}.113^{\star \star \star} \\
(.036)\end{array}$ \\
\hline Population $_{t-1}$ & & $\begin{array}{l}.063 \\
(.067)\end{array}$ & & & & \\
\hline Density $_{t-1}$ & $\begin{array}{l}-.094 \\
(.093)\end{array}$ & & $\begin{array}{l}-.066 \\
(.090)\end{array}$ & $\begin{array}{l}-.099^{\star \star \star} \\
(.094)\end{array}$ & $\begin{array}{l}-.046 \\
(.090)\end{array}$ & $\begin{array}{l}.037 \\
(.085)\end{array}$ \\
\hline Urbanization $_{t-1}$ & & $\begin{array}{l}-.277 \\
(.373)\end{array}$ & & & & \\
\hline Growth rate t & $\begin{array}{l}.036 \\
(.055)\end{array}$ & $\begin{array}{l}-.015 \\
(.050)\end{array}$ & $\begin{array}{l}.040 \\
(.053)\end{array}$ & $\begin{array}{l}.034 \\
(.055)\end{array}$ & $\begin{array}{l}.033 \\
(.055)\end{array}$ & $\begin{array}{l}.032 \\
(.051)\end{array}$ \\
\hline Unemployment $_{t-1}$ & & & & & & $\begin{array}{l}.449^{\star \star \star} \\
(.115)\end{array}$ \\
\hline Trade openness $s_{t-1}$ & & & $\begin{array}{l}.042 \\
(.045)\end{array}$ & & & \\
\hline$E U \exp _{t-1}$ & & & & $\begin{array}{l}.003 \\
(.007)\end{array}$ & & \\
\hline$E U$ trade $_{t-1}$ & & & & & $\begin{array}{l}-.067 \\
(.072)\end{array}$ & \\
\hline Reunification & $\begin{array}{l}-.017 \\
(.012)\end{array}$ & $\begin{array}{l}-.016 \\
(.019)\end{array}$ & $\begin{array}{l}-.006 \\
(.015)\end{array}$ & $\begin{array}{l}-.017 \\
(.012)\end{array}$ & $\begin{array}{l}-.009 \\
(.013)\end{array}$ & $\begin{array}{l}.009 \\
(.009)\end{array}$ \\
\hline Postwar & $\begin{array}{l}.014^{\star} \\
(.007)\end{array}$ & & $\begin{array}{l}-.011 \\
(.008)\end{array}$ & $\begin{array}{l}-.016^{\star} \\
(.008)\end{array}$ & $\begin{array}{l}-.010 \\
(.010)\end{array}$ & $\begin{array}{l}-.018^{\star \star} \\
(.007)\end{array}$ \\
\hline Trend & $\begin{array}{l}.000 \\
(.001)\end{array}$ & & $\begin{array}{l}-.000 \\
(.001)\end{array}$ & $\begin{array}{l}.000 \\
(.001)\end{array}$ & $\begin{array}{l}.000 \\
(.001)\end{array}$ & $\begin{array}{l}-.003^{\star \star \star} \\
(.001)\end{array}$ \\
\hline No. obs. & 49 & 39 & 49 & 49 & 49 & 49 \\
\hline $\mathrm{R}^{2}$ & .971 & .953 & .972 & .971 & .971 & .976 \\
\hline adj. $R^{2}$ & .966 & .944 & .966 & .965 & .966 & .972 \\
\hline $\mathrm{BG}(1)$ & 7.433 & 0.007 & 5.722 & 6.201 & 6.219 & 5.032 \\
\hline $\mathrm{BG}(2)$ & 7.942 & 0.008 & 5.778 & 6.441 & 6.865 & 5.058 \\
\hline
\end{tabular}

Note: Due to serial correlation, Newey-West heteroscedasticity and autocorrelation consistent standard errors $(\mathrm{L}=3)$ are reported in brackets. ${ }^{* * *}, * *$, and $*$ indicate significance at $1 \%, 5 \%$ and $10 \%$ levels, respectively. 


\section{Data Sources and Definitions}

Density Natural log of population density, inhabitants per $\mathrm{km}^{2}$. [Source: IMF; World Bank]

Dependency ratio Proportion of population aged below 15 or above 64. [Source: OECD, Labor Force Statistics. Own calculations]

EU expenditure Expenditure of the European Union in \% of total public expenditure of EU member countries. [Source: Europäische Kommission (2000)]

EU trade Exports plus imports to/from EU15 as a share of foreign trade. [Source: Sachverständigenrat (1997, 2002, 2004). Own calculations]

Growth rate Rate of growth of real GDP per capita. [Source: 1950-69 Stat. Bundesamt (1991a), 1970-2002 Sachverständigenrat $(2002,2004)$. Own calculations]

Per capita income Natural log of real GDP per capita, in prices of 1995 and in EUR, partly reckoned back. [Source: 1950-69 Stat. Bundesamt (1991a), 1970-2002 Sachverständigenrat (2002, 2004). Own calculations]

Population Natural log of population in 1000. [Source: IMF; World Bank]

Size of the public sector Public expenditure (national income statistics) including / excluding social security, as percent of net national product. Total public expenditures reported by Hoffmann (1965) for 1850-1938 include public consumption, current transfers, interest payments, and partly net public investment. Note that social security is understated, including only administrative expenditure for this period. [Source: 1850-1938 Hoffmann (1965), 1950-1969 Stat. Bundesamt (1991a, 1991b), 1970-2003 Sachverständigenrat (2003) drawing on data from Stat. Bundesamt. Own calculations]

Degree of expenditure decentralization (total) Public expenditure (financial statistics) by level of government, as percent of total expenditure of consolidated government (excluding EU payments), including / excluding social security. Lastenausgleichfonds and ERP-Vermögen are allocated to the central government. Partly different expenditure concepts, not strictly comparable. Excluding social security: 1881-1913 direct expenditure, 1925-2001 self-financed expenditure. Including social security: 1881-1958 direct expenditure, 1974-2001 self-financed expenditure, missing social security data for the years in between. [Source: 1881-1958 direct expenditure (partly interpolated figures), Andic and Veverka (1963); 1925-2001 self-financed expenditure, Kraus (1983), Statistisches Bundesamt (1961, 1972, 1996, 2000, 2001). Own calculations]

Degree of expenditure decentralization (government functions) Public expenditure (financial statistics) by government function and level of government, including / excluding social security. Partly different expenditure concepts, not strictly comparable. Including social security: 1881-1958 direct expenditure, 1974-2001 self-financed expenditure. Excluding social security: 1881-1937 direct expenditure, 1950-2001 self-financed expenditure. Data for transport \& communication, other economic services, school, and university in terms of self-expenditure are derived for 1913-1932 from Statistisches Bundesamt (1972). [Source: 1881-1958 direct expenditure (partly interpolated figures), Andic and Veverka (1963); 1950-2001 self-financed expenditure (partly interpolated figures), Stat. Bundesamt (1996, 2000, 2001). Own calculations]

Degree of tax decentralization Tax revenue (financial statistics) by level of government, as percent of total tax revenue of consolidated general government, excluding social security. Figures for 1881-1913 are interpolated. [Source: 1881-1949 data compiled by Kraus (1983) from national statistics; 1950-2001 Stat. Bundesamt (1972, 1996, 2000, 2001). Own calculations]

Trade openness Exports plus imports as a share of gross domestic product. [Source: 1950-69 Stat. Bundesamt (1991a), 1970-2002 Sachverständigenrat (2002, 2004). Own calculations]

Urbanization Fraction of urban population. [Source: Eurostat; OECD; World Bank]

\section{Territory}

1850-1913 German Kaiserreich, frontiers of 1913 (until 1870 without Elsass-Lothringen)

1925-1938 Germany, frontiers of 1925 (without Austria and Sudetenland, since 1934 with Saarland) 1950-2003 Federal Republic of Germany, until 1990 without German Democratic Republic (until 1959 also without Saarland and West Berlin) 


\section{Classification of government functions, 1881-2001}

- Administration \& Other: general government, internal, tax and other administration, other unallocated functions

- Law \& Order: public security, police, courts, attorneys, prisons

- Defense

- Education: schools (general, vocational), universities, science \& research (extra-university), other education (support of education, etc.)

- Social Assistance \& War Damage Compensation: social welfare, family benefits, youth welfare, war effects, other social affairs

- Social Security: unemployment, health, invalidity and retirement insurance

- Health: hospitals, other health affairs, sports and recreation, environmental protection

- Housing: housing, area planning, city development

- Economic/Trading Services: transport and communication (railways, public transportation, roads), other economic services (regional and economic development, public enterprises, food and agriculture, other manufacturing services, real estate, capital income)

- Communal/Environmental Services

\section{Descriptive Statistics (1950-2001)}

\begin{tabular}{lcccc}
\hline \hline Variable & Mean & Std.Dev. & Min. & Max. \\
\hline Degree of fiscal decentralization: & & & & \\
self-financed expenditure (total, excl. social security) & .530 & .029 & .455 & .566 \\
self-financed expenditure (total, excl. soc. sec. and defense) & .587 & .023 & .537 & .627 \\
self-financed expenditure (other economic services) & .514 & .076 & .341 & .632 \\
self-financed expenditure (transport and communications) & .592 & .073 & .493 & .736 \\
total tax revenue & .467 & .044 & .377 & .522 \\
Population & 11.040 & .149 & 10.820 & 11.319 \\
Density & 5.452 & .064 & 5.303 & 5.537 \\
Urbanization & .826 & .036 & .761 & .880 \\
Per capita income & 9.585 & .448 & 8.506 & 10.091 \\
Dependency ratio & .331 & .015 & .304 & .364 \\
Unemployment & .056 & .040 & .005 & .127 \\
Growth rate & .033 & .034 & -.071 & .137 \\
Trade openness & .467 & .108 & .265 & .686 \\
EU expenditure & 1.231 & .899 & .000 & 2.400 \\
EU trade & .485 & .066 & .351 & .615 \\
\hline \hline
\end{tabular}




\section{References}

Albers, W. (1964), Das Popitz'sche Gesetz der Anziehungskraft des übergeordneten Haushalts, in: F. Neumark (ed.), Strukturwandlungen einer wachsenden Wirtschaft, Berlin.

Alesina, A. and E. Spolaore (1997), On the Number and Size of Nations, The Quarterly Journal of Economics 112(4), 1027-1056.

ANDic, S. and J. VEverkA (1963), The growth of government expenditure in Germany since the unification (1871), Finanzarchiv N.F. 23 Heft 2, 169-278.

Behnisch, A., Buettner, T. and D. Stegarescu (2002), Public Sector Centralization and Productivity Growth: Reviewing the German Experience, ZEW Discussion Paper No. 02-03, Mannheim.

Blankart, C. B. (1999), Die schleichende Zentralisierung der Staatstätigkeit: Eine Fallstudie, Zeitschrift für Wirtschafts- und Sozialwissenschaften 119, 331-350.

Blankart, C. B. (2000), The Process of Government Centralization: A Constitutional View, Constitutional Political Economy 11, 27-39.

Blankart, C. B. (2001), Popitz Law, Bryce's Law and Government Centralization in Prussia and in Germany, Journal of Public Finance and Public Choice 19(1), 71-81.

Brecht, A. (1932), Internationaler Vergleich öffentlicher Ausgaben, Grundfragen der internationalen Politik 2, Leipzig.

Brennan, G. and J. Buchanan (1980), The Power to Tax-Analytical Foundations of a Fiscal Constitution, Cambridge.

Buettner, T., R. Schwager and D. Stegarescu (2004), Agglomeration, Population Size, and the Cost of Providing Public Services: An Emprical Analysis for German States, Public Finance and Management $4(4)$, forthcoming.

Burg, P. (1992), Der Föderalismus im Kaiserreich. Politische Strukturen und Prozesse, in: Huhn, J. and P.C. Witt (eds.), Föderalismus in Deutschland. Traditionen und gegenwärtige Probleme, Baden-Baden, 55-74.

DöHLER, E. (2002), Autonome Besteuerungsrechte für Gliedstaaten und Gemeinden in ausgewählten föderativen Finanzverfassungen, INFER Research Edition Vol. 7, Berlin.

EuropäIsche Kommission (2000), Haushaltsvademekum 2000, Brussels.

Gerloff, W. (1913), Die Finanz- und Zollpolitik des Deutschen Reiches nebst ihren Beziehungen zu Landesund Gemeindefinanzen von der Gründung des Norddeutschen Bundes bis zur Gegenwart, Jena.

Granger, C. W. J. (1969), Investigating Causal Relations by Econometric Models and Cross-Spectral Methods, Econometrica 37(3), 424-438.

Granger, C. W. J. and P. Newbold (1974), Spurious Regressions in Econometrics, Journal of Econometrics $2,111-120$.

Greene, W. H. (2000), Econometric Analysis, 4th ed., Prentice Hall.

Hansmeyer, K.-H. (1967), Das Popitzsche Gesetz von der Anziehungskraft des zentralen Etats, in: Timm, H. and C.-A. Andreae (eds.), Beiträge zur Theorie der öffentlichen Ausgaben, Berlin : Duncker \& Humblot, $197-229$.

Hansmeyer, K.-H. and K. Zimmermann (1984), Das Popitzsche Gesetz und die Entwicklung der Aufgabenverteilung zwischen Bund und Ländern in den 60er und 70er Jahren, in: Koch, W. and H.-G. Petersen (eds.), Staat, Steuern und Finanzausgleich. Festschrift für Heinz Kolms zum 70. Geburtstag, Berlin : Duncker und Humblot, 297-314.

Hesse, K. (1962), Der unitarische Bundesstaat, Karlsruhe.

Hoffmann, W. G. (1965), Das Wachstum der deutschen Wirtschaft seit der Mitte des 19. Jahrhunderts, Berlin.

Kraus, A. (1983), Zentrale und dezentrale Tendenzen im Föderalismus, Göttingen: Vandenhoeck \& Ruprecht.

Kunn, T. (1993), Determinanten der Staatsausgaben: Bevölkerung und Urbanisierung, Eine Literaturübersicht, Ifo Studien - Zeitschrift für empirische Wirtschaftsforschung 39. Jg. / 1-4, 127-145.

Legler, J.B., Sylla, R. and J.J. Wallis (1988), U.S. city finances and the growth of government, 1850-1902, The Journal of Economic History Vol. XLVIII, No. 2, p.347-356. 
Meyer, S. (1998), Popitz' "Gesetz der Anziehungskraft des zentralen Etats" Erklärungsansatz für Zentralisierungstendenzen im europäischen Integrationsprozess?, WiSt 4, 197-200.

Neumark, F. (1976), Die Finanzpolitik in der Zeit vor dem I. Weltkrieg, in: Deutsche Bundesbank (Ed.), Währung und Wirtschaft in Deutschland 1876-1975, Frankfurt am Main, 57-111.

OAtes, W. E. (1972), Fiscal Federalism, New York etc.

PEACOCK, A.T. and J. Wiseman (1961), The growth of public expenditure in the United Kingdom, 2nd edn. 1967, London.

Peltzman, S. (1980), The Growth of Government, The Journal of Law ES Economics, Vol. 23(2), 209-287.

Pfetsch, F. R. (1974), Zur Entwicklung der Wissenschaftspolitik in Deutschland 1750-1914, Berlin.

Popitz, J. (1927), Der Finanzausgleich, in: Gerloff, W. and F. Meisel, Handbuch der Finanzwissenschaft 2. Band, Tübingen, 338ff.

Pryor, F. L. (1968), Public Expenditures in Communist and Capitalist Nations, London: George Allen and Unwin Ltd.

Ram, R. (1987), Wagner's Hypothesis in Time-Series and Cross-Section Perspectives: Evidence from "Real" Data for 115 Countries, The Review of Economics and Statistics, 69(2), 194-204.

Recktenwald, H. C. (1962), Die Entwicklung der öffentlichen Ausgaben in der Bundesrepublik, in: König, H. (ed.), Wandlungen der Wirtschaftsstruktur in der Bundesrepublik Deutschland, Schriften des Vereins für Socialpolitik, N.F. Vol. 26, Berlin, 199-248.

Recktenwald, H. C. (1975), Umfang und Struktur der öffentlichen Ausgaben in säkularer Entwicklung, in: Andel, N., Haller, H. and F. Neumark (eds.), Handbuch der Finanzwissenschaft Vol.1, 3rd edn.

Recktenwald, H. C. (1984), Föderalismus im säkularen Wandel. Erste Ergebnisse einer empirischen Analyse, in: Koch, W. and H.-G. Petersen (eds.), Staat, Steuern und Finanzausgleich. Festschrift für Heinz Kolms zum 70. Geburtstag, Berlin : Duncker und Humblot, 279-295.

Reichsschatzamt (1908), Denkschriftenband zur Begründung des Entwurfs eines Gesetzes betreffend Änderungen im Finanzwesen, Berlin.

Sachverständigenrat zur Begutachtung Der Gesamtwirtschaftlichen Entwicklung (2003), Staatsfinanzen konsolidieren - Steuersystem reformieren, Jahresgutachten 2003/04, Wiesbaden.

Scharpf, F.W., Reissert, B. and F. Schnabel (1976), Politikverflechtung. Theorie und Empirie des kooperativen Föderalismus in der Bundesrepublik, Kronberg.

Schremmer, E. (1994), Steuern und Staatsfinanzen während der Industrialisierung Europas: England, Frankreich, Preußen und das Deutsche Reich 1800 bis 1914, Berlin, etc.

Statistisches Bundesamt (1961), Statistik der Bundesrepublik Deutschland, Band 259 . Öffentliche Finanzwirtschaft in den Rechnungsjahren 1957 und 1958, Stuttgart.

Statistisches Bundesamt (1972), Bevölkerung und Wirtschaft 1872-1972, Stuttgart.

Statistisches Bundesamt (1991a), Volkswirtschaftliche Gesamtrechnungen. Revidierte Ergebnisse 1950 bis 1990, Fachserie 18, Reihe S.15, Wiesbaden.

Statistisches BundesAmT (1991b), Volkswirtschaftliche Gesamtrechnungen. Der Staat in den Volkswirtschaftlichen Gesamtrechnungen 1950 bis 1990 Fachserie 18, Reihe S.16, Wiesbaden.

Statistisches Bundesamt (1996), Öffentliche Finanzen. Rechnungsergebnisse des öffentlichen Gesamthaushalts 1996. Fachserie 14, Reihe 3.1, Wiesbaden.

Statistisches Bundesamt (2000), Öffentliche Finanzen. Rechnungsergebnisse des öffentlichen Gesamthaushalts 2000. Fachserie 14, Reihe 3.1, Wiesbaden.

Statistisches Bundesamt (2001), Öffentliche Finanzen. Rechnungsergebnisse des öffentlichen Gesamthaushalts 2001. Fachserie 14, Reihe 3.1, Wiesbaden.

Stegarescu, D. (2004a), Public Sector Decentralization: Measurement Concepts and Recent International Trends, ZEW Discussion Paper No. 04-74, Mannheim.

Stegarescu, D. (2004b), Economic Integration and Fiscal Decentralization: Evidence from OECD Countries, ZEW Discussion Paper No. 04-86, Mannheim. 
Terhalle, F. (1952), Geschichte der deutschen öffentlichen Finanzwirtschaft vom Beginn des 19. Jahrhunderts bis zum Schlusse des Zweiten Weltkrieges, in: Gerloff, W. and F. Neumark (eds.), Handbuch der Finanzwissenschaft, Band 1, 2.ed., Tübingen, ...

TILly, R. (1997), Kommunalfinanzen und -investitionen im Deutschen Kaiserreich, 1870-1914: Quantifizierungsansätze, in: Gerhard, H.-J. (ed.), Struktur und Dimension. Festschrift für Karl Heinrich Kaufhold zum 65.Geburtstag. Band 2: Neunzehntes und Zwanzigstes Jahrhundert, VSWG Beiheft 133, 134-166.

De Tocqueville, A. (1840), De la démocratie en Amérique II, electronic edition.

WaGner, A. (1876), Grundlegung der politischen Ökonomie. Bd. 1: Grundlagen der Volkswirtschaft, 3. ed., Leipzig.

Witt, P.-C. (1992), Finanzen und Politik im Bundesstaat-Deutschland 1871-1933, in: Huhn, J. and P.-C. Witt (eds.), Föderalismus in Deutschland. Traditionen und gegenwärtige Probleme, Baden-Baden, 75-100. 